\title{
Reconciling regional continuity with local variability in structure, uplift and exhumation of the Timor orogen
}

\author{
Garrett W. Tate ${ }^{\mathrm{a}, *}$, Nadine McQuarrie ${ }^{\mathrm{b}}$, Herwin Tiranda ${ }^{\mathrm{c}}$, Douwe J.J. van Hinsbergen ${ }^{\mathrm{d}}$, Ron Harris ${ }^{\mathrm{e}}$, \\ Willem Jan Zachariasse ${ }^{\mathrm{d}}$, Maria Giuditta Fellin ${ }^{\mathrm{f}}$, Peter W. Reiners ${ }^{\mathrm{g}}$, Sean D. Willett ${ }^{\mathrm{f}}$ \\ a Department of Earth and Environmental Sciences, Vanderbilt University, Nashville, TN, USA \\ ${ }^{\mathrm{b}}$ Department of Geology and Planetary Science, University of Pittsburgh, Pittsburgh, PA, USA \\ c Bandung Institute of Technology, Bandung, Indonesia \\ d Department of Earth Sciences, Utrecht University, Utrecht, Netherlands \\ e Department of Geological Sciences, Brigham Young University, Provo, UT, USA \\ ${ }^{\mathrm{f}}$ Department of Earth Sciences, ETH Zurich, Switzerland \\ ${ }^{g}$ Department of Geosciences, University of Arizona, Tucson, AZ, USA
}

\section{A R T I C L E I N F O}

\section{Article history:}

Received 21 June 2016

Received in revised form 15 May 2017

Accepted 1 June 2017

Available online 20 June 2017

Handling Editor: S. Kwon

\begin{abstract}
A B S T R A C T
Along-strike variations in orogenic development can be difficult to constrain. Resulting assumptions projecting similarity or variability along strike can lead to erroneous conclusions at the orogen scale. Young orogens provide opportunities to document limits of along-strike projection and test factors that may control lateral variability. Here we present new constraints on the history of uplift, exhumation and shortening in the Timor orogen from West Timor, Indonesia. Structural mapping documents a foreland thrust stack of Jurassic-Miocene Australian margin strata and a hinterland antiformal stack of Permo-Triassic Australian continental units duplexed below Banda Arc lithosphere. Biostratigraphy within the piggyback Central Basin reveals earliest deepwater synorogenic deposition at 5.57-5.53 Ma, uplift from lower to middle bathyal depths at 3.35-2.58 Ma, and uplift from middle to upper bathyal depths at 2.58-1.30 Ma. Hinterland Permo-Triassic strata yield apatite (U-Th)/He ages of 0.33-2.76 Ma, apatite fission track ages of 2.19-3.53 Ma and partially reset zircon (U-Th)/He ages. These thermochronology ages are youngest or most strongly reset in the center of the antiformal stack and yield modeled exhumation rates of $0.45-3.31 \mathrm{~km} / \mathrm{Myr}$. A balanced cross section reveals a minimum of $300 \mathrm{~km}$ of shortening including $210 \mathrm{~km}$ of Australian continental subduction below the Banda forearc. When compared to published results from Timor-Leste, these data show that the timing of initial collision, synorogenic basin uplift, and total shortening amount were broadly similar across the island. Therefore, despite along-strike changes in orogen morphology and significant small-scale spatial variability in deformation, first-order structural similarity dominates at large scales. We suggest that along-strike variations in orogen morphology are due to changes in the distribution of deformation within the orogen driven by differences in backstop strength, internal wedge strength and basal décollement friction as well as the presence of the wedge-top Central Basin in West Timor.
\end{abstract}

C 2017 International Association for Gondwana Research. Published by Elsevier B.V. All rights reserved.

\section{Introduction}

The geologic records of the world's mountain belts hold important information on geodynamics, fault kinematics, paleogeography, and plate tectonic history. Along-strike variations in orogen topography, width, and exhumation can be important clues for unlocking that information, as they indicate that certain factors controlling orogen development may vary through space or time. In Taiwan, for example, oblique collision has caused propagation of deformation along strike (Suppe, 1984), producing a spatial gradient in shortening age and magnitude,

\footnotetext{
* Corresponding author.

E-mail address: g.tate@vanderbilt.edu (G.W. Tate).
}

topography (Suppe, 1981) and exhumation (Willett et al., 2003). In the Andes, climate variations along strike have been tied to changes in orogen width, topography and exhumation magnitude, suggesting that climatic controls may even be as important as tectonic forcings (Montgomery et al., 2001). In the Mediterranean, pre-existing heterogeneities such as paleogeographic ocean-continent distribution lead to highly variable orogenic strike direction, width, age, and topographic style (Stampfli and Hochard, 2009; Gaina et al., 2013; van Hinsbergen et al., 2014). Additionally, surface uplift may reflect a dynamic topographic origin, such as that resulting from lateral propagation of slab break-off (e.g. van der Meulen et al., 2000).

Through time, erosion often causes loss of the rock record necessary to fully characterize the shortening and uplift history of a mountain belt. 
Such challenges caused by imperfect preservation might lead to erroneous interpretations based on either 1) assumptions of orogenic cylindricity, i.e. projecting the timing of deformation or geometry of structures along strike in regions of sparse data, or 2) generalizations of local structural heterogeneities to the broad orogen scale. In Timor, however, orogenesis has occurred only since the late Miocene (Berry and McDougall, 1986; Keep and Haig, 2010; Tate et al., 2014), and surface exposures include piggyback basins recording the earliest stages of uplift (Haig and McCartain, 2007; Tate et al., 2014) in close proximity to the exhumed deformational core of the mountain belt (Audley-Charles, 1968; Tate et al., 2014; Tate et al., 2015). Determining the structural evolution and history of surface and rock uplift of a single mountain belt in multiple locations along strike provides an opportunity to evaluate the interplay between various controls on orogen development (timing of collision, surface processes, rock mechanical properties, etc.) and gain insight into their relative importance in determining orogen morphology.

In this paper we present new structural mapping, micropaleontology of synorogenic deep-marine sedimentary basins, low-temperature thermochronology data interpreted with thermal modeling, and a balanced cross section across West Timor. We compare these results to correlative data in Timor-Leste (East Timor), which will allow us to rigorously document along-strike variations in orogenic development and evaluate the mechanisms that may account for these variations.

\section{Geologic setting}

\subsection{The age of collision}

Timor is located at the collisional boundary between the northern Australian continental margin and the Banda volcanic arc (Fig. 1). A variety of methods have been employed to date the timing of this collision, which rely on different definitions of collision and have therefore led to different ages. Constraints on the collision age include the youngest pre-collisional strata (Haig and McCartain, 2007), the oldest collisional thermochronometric ages (Berry and McDougall, 1986; Tate et al., 2014), structural shortening and plate convergence rates (Tate et al., 2015), fault activity due to flexure of the Australian margin (Saqab et al., 2017), the oldest synorogenic strata (Haig and McCartain, 2007; Tate et al., 2014), the age of continental contamination in Banda Arc volcanics (Elburg et al., 2004; Herrington et al., 2011), and the youngest volcanics in the segment of the Banda Arc north of Timor (Abbott and Chamalaun, 1981; Ely et al., 2011; Herrington et al., 2011).

The oldest pre-collisional strata are found to be $9.8 \mathrm{Ma}$ in TimorLeste (Haig and McCartain, 2007). This constraint gives a maximum age for collision, although it is potentially challenged by preservation of strata, depositional hiatuses, or spatial propagation of deformation timing.
Thermochronometric ages date rock exhumation and cooling and the oldest ages attempt to constrain the minimum age of collision. In Timor these ages are as old as 7.5 Ma (Berry and McDougall, 1986) or $7.1 \pm 0.3 \mathrm{Ma}$ (Tate et al., 2014) for ${ }^{40} \mathrm{Ar} /{ }^{39} \mathrm{Ar}$ analyses in the highgrade Aileu belt of Timor-Leste and 5.5 $\pm 0.1 \mathrm{Ma}$ for (U-Th)/He analyses in the Australian-affinity Gondwana Sequence of Timor-Leste (Tate et al., 2014). Debate surrounds the tectonic affinity of the high-grade Aileu belt in Timor-Leste (e.g. Audley-Charles, 2011; Ely et al., 2014), such that the exhumation age of this unit may reflect a different tectonic event or deformation within the Banda forearc instead of collision at Timor. Even so, (U-Th)/He ages as old as $5.5 \pm 0.1 \mathrm{Ma}$ in unquestioned Australian-affinity units point to orogenesis at Timor by the end of the Miocene (Tate et al., 2014).

Shortening estimates in two balanced cross sections in Timor-Leste compared to plate convergence rates estimate that shortening must have begun by $7.8 \mathrm{Ma}$ or 7.3 Ma depending on whether the above exhumation ages in the Aileu high-grade belt are or are not indicative of collision, respectively (Tate et al., 2015).

Saqab et al. (2017) use seismic reflection and well data to interpret a phase of normal faulting on the Australian margin beginning at about $6 \mathrm{Ma}$. Those authors attribute this normal faulting to flexure of the Australian margin coincident with the onset of arc-continent collision.

The oldest synorogenic strata in Timor-Leste (deposited in piggyback basins on top of units that were deformed during collision, see Section 3.4.2) are 5.6-5.2 Ma (Haig and McCartain, 2007) or 5.57$5.53 \mathrm{Ma}$ (Tate et al., 2014), providing another minimum collision age.

Banda Arc volcanics north of Timor were contaminated with continental $\mathrm{He}$, Pb and $\mathrm{Sr}$ isotopic signatures from 5 to $2.4 \mathrm{Ma}$ (Elburg et al., 2004; Herrington et al., 2011). This is a minimum constraint on the collision age, as material from the Australian margin must have been subducted down to magma-generating depths by this time.

Lastly, volcanism on islands north of Timor ceased between 3.3 and 2.4 Ma (Abbott and Chamalaun, 1981; Ely et al., 2011; Herrington et al., 2011), which provides another minimum constraint on the age of collision as it records either slab breakoff (Ely et al., 2011) or subducting the continental margin to magma-generating depths (Herrington et al., 2011).

With such a wide variety of collision indicators, authors have referred to a wide variety of ages as the age of collision between the Banda Arc and Australia (e.g. Keep and Haig, 2010; Spakman and Hall, 2010; Audley-Charles, 2011). We would suggest that this variety of ages is in large part simply due to authors referring to different stages of collision. Indeed, the millions of years found between the earliest and latest age constraints above, as well as the style of deformation and magnitude of shortening documented in Timor-Leste, support the conclusion that arc-continent collision has been a prolonged process in Timor (Tate et al., 2015). To be clear, in this paper we will refer to initial collision as the first contact between the Banda forearc and the

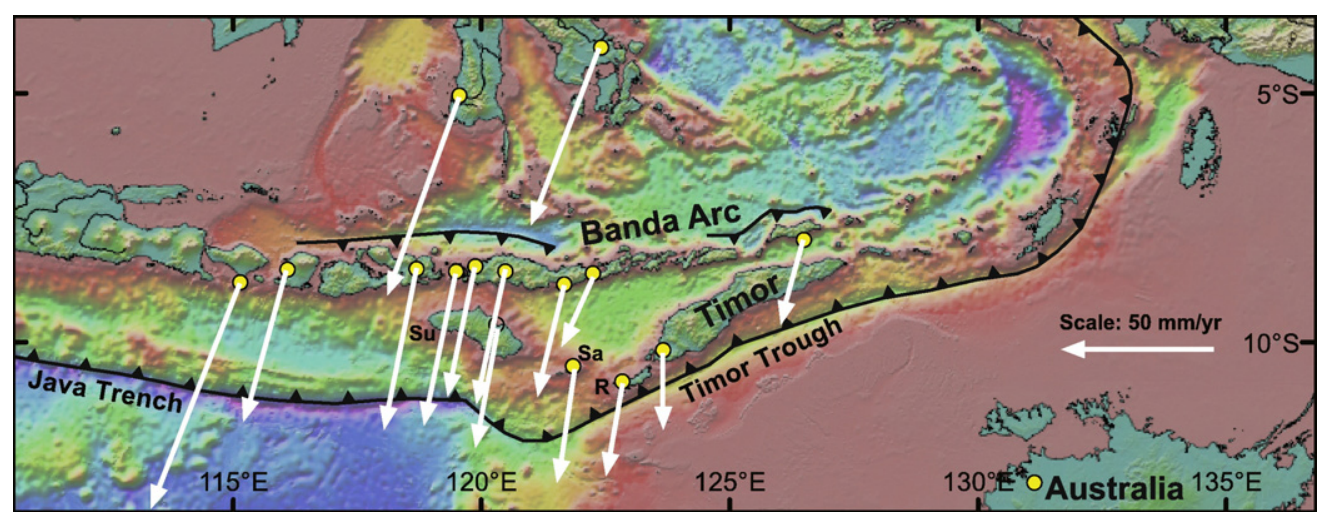

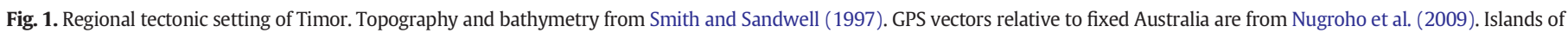
Sumba, Savu and Rote indicated by Su, Sa and R, respectively. 
Australian margin, when deformation of Banda forearc units and Australian sedimentary strata would have begun. GPS measurements suggest that this shortening between Timor and Australia remains active at the present day (Fig. 1 and Nugroho et al., 2009).

\subsection{Style of deformation}

In both Timor-Leste (East Timor) (Audley-Charles, 1968; Harris, 1991; Zobell, 2007; Standley and Harris, 2009; Tate et al., 2015) and West Timor (Rosidi et al., 1979; Bird and Cook, 1991), structural mapping highlights that significant portions of the orogenic wedge have developed by duplexing of Permo-Triassic sedimentary strata derived from Australian continental crust below an overthrust lid of Banda oceanic forearc rocks. This duplex in West Timor is revealed most prominently in the Kekneno window (Rosidi et al., 1979; Bird and Cook, 1991). Late Jurassic and younger Australian margin strata are deformed into a thrust wedge at the leading edge of the Banda overthrust sheet (Carter et al., 1976; Harris, 1991; Harris, 2006). The onshore expression of this thrust belt is the Kolbano range on the southern coast of West Timor (Rosidi et al., 1979; Charlton et al., 1991; Sawyer et al., 1993). The Bobonaro mélange is a lithotectonic unit structurally between the duplex of Permo-Triassic strata and the overthrust Banda forearc or Kolbano thrust belt (Harris et al., 1998). This mélange contains blocks of each tectonostratigraphic unit entrained in a shale matrix mostly derived from Jurassic Australian strata (Harris et al., 1998). Piggyback basins across Timor preserve outcrops of the deep marine synorogenic Viqueque Sequence, which contains pelagic carbonates overlain by clays and turbiditic sandstones (Audley-Charles, 1968). The largest of these piggyback basins is the Central Basin, an approximately $100 \mathrm{~km}-$ long basin parallel to the axis of West Timor (Rosidi et al., 1979). Viqueque Sequence deposits directly overly the Bobonaro mélange, a contact which implies that a) Viqueque Sequence deposition began after the start of orogenesis, and b) some of the mélange was exhumed to the seafloor (Tate et al., 2014) or emplaced above the Kolbano thrust stack (Barber et al., 1986; Harris, 2011).

\subsection{West Timor and East Timor (Timor-Leste)}

Significant lateral variation in uplift and exhumation has been documented at small spatial scales in Timor-Leste, with some synorogenic basin deposits preserved within $10 \mathrm{~km}$ of an area that underwent 3$7 \mathrm{~km}$ of exhumation since the Pliocene (Tate et al., 2014). Similarly, small-wavelength variations in the uplift rates of coral terraces have been documented across the island (Merritts et al., 1998; Cox, 2009). With such large local variability, it is possible that the timing and amount of uplift and exhumation are significantly different several hundred kilometers away in West Timor.

Indeed, a number of previous studies have suggested a progression of deformation from east to west across Timor. Foraminiferal studies of synorogenic basins have shown that pelagic carbonate deposition on the Bobonaro mélange began at 5.57-5.53 Ma in Timor-Leste (Haig and McCartain, 2007; Tate et al., 2014; Aben et al., 2014). Published biostratigraphy from the Central Basin in West Timor suggested that this synorogenic deposition instead began there around $3 \mathrm{Ma}$ (De Smet et al., 1990). If correct, this acts as a much younger minimum constraint on the age of initial collision in West Timor than Timor-Leste. Similarly, significant uplift of the synorogenic basins from lower to middle bathyal depths was dated at 3.35 to 3.0 Ma in eastern Timor-Leste (Haig and McCartain, 2007; Aben et al., 2014; Tate et al., 2014) but only at 2.2 to 2.0 Ma in West Timor (De Smet et al., 1990) suggesting later orogenic development in West Timor. Furthermore, if recent uplift of Timor is due to isostatic rebound following slab breakoff, as postulated by Keep and Haig (2010), this could suggest a laterally propagating tear of the slab from east to west. (We note however that the aforementioned small-wavelength uplift patterns suggest active deformation mechanisms at a smaller scale than isostatic rebound.)
Some plate reconstructions support the hypothesis that deformation propagated east to west across Timor. Obliquity of the Australian margin relative to the subduction zone below the Banda forearc, coupled with reconstructions suggesting that the magnitude of exhumation and backthrusting decrease from Timor west to the islands of Rote, Savu and Sumba (Fig. 1), has led to the interpretation that arc-continent collision has generally propagated from east to west at the rate of about $110 \mathrm{~km} / \mathrm{Myr}$ along strike (Harris, 1991). Alternatively, other hypotheses suggest that instead of a gradual diachroneity, continental subduction across the whole of Timor occurred earlier than at smaller islands along strike due to initial subduction of a continental plateau protruding from the Australian margin (Keep and Haig, 2010). This alternative hypothesis would predict broadly similar collision and shortening histories in eastern and western Timor and less shortening (as well as younger initiation of continental subduction) at other islands east and west of Timor because of embayments in the subducted Australian margin.

The data presented here will allow us to test the hypothesis of east to west propagation of deformation against an alternative scenario of synchronous initial collision along strike. Further, if the alternative scenario of broad-scale synchronicity holds, we will be able to explore the mechanisms that still allow for persistent morphological differences and local deformational variability along strike.

\section{Tectonostratigraphy}

A generalized tectonostratigraphy of West Timor is shown in Fig. 2. This tectonostratigraphy consists of four main divisions: the Gondwana Sequence (Fig. 3) and Kolbano Sequence (Fig. 4) (both with Australian Affinity), the Banda Terrane (with Banda Arc affinity), and the Banda Orogen Sequence (which formed during orogenesis at Timor).

\subsection{Gondwana Sequence}

The Gondwana Sequence (Harris et al., 1998) (also referred to as the Kekneno Sequence in West Timor (Bird and Cook, 1991)) is composed of strata deposited on the Australian continent prior to Gondwana breakup (Fig. 2). These Permian to Jurassic units are interpreted to have been deposited in failed-rift or intra-continental basins (Bird and Cook, 1991). Paleo-current (Bird and Cook, 1991) and some detrital

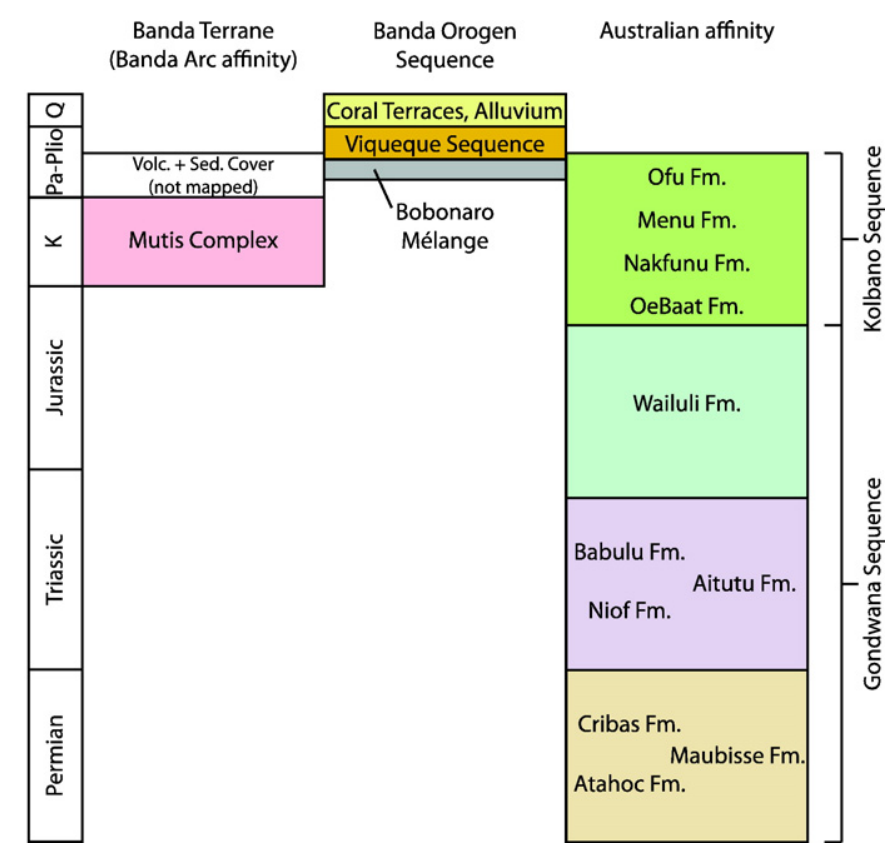

Fig. 2. Simplified tectonostratigraphy of West Timor. 


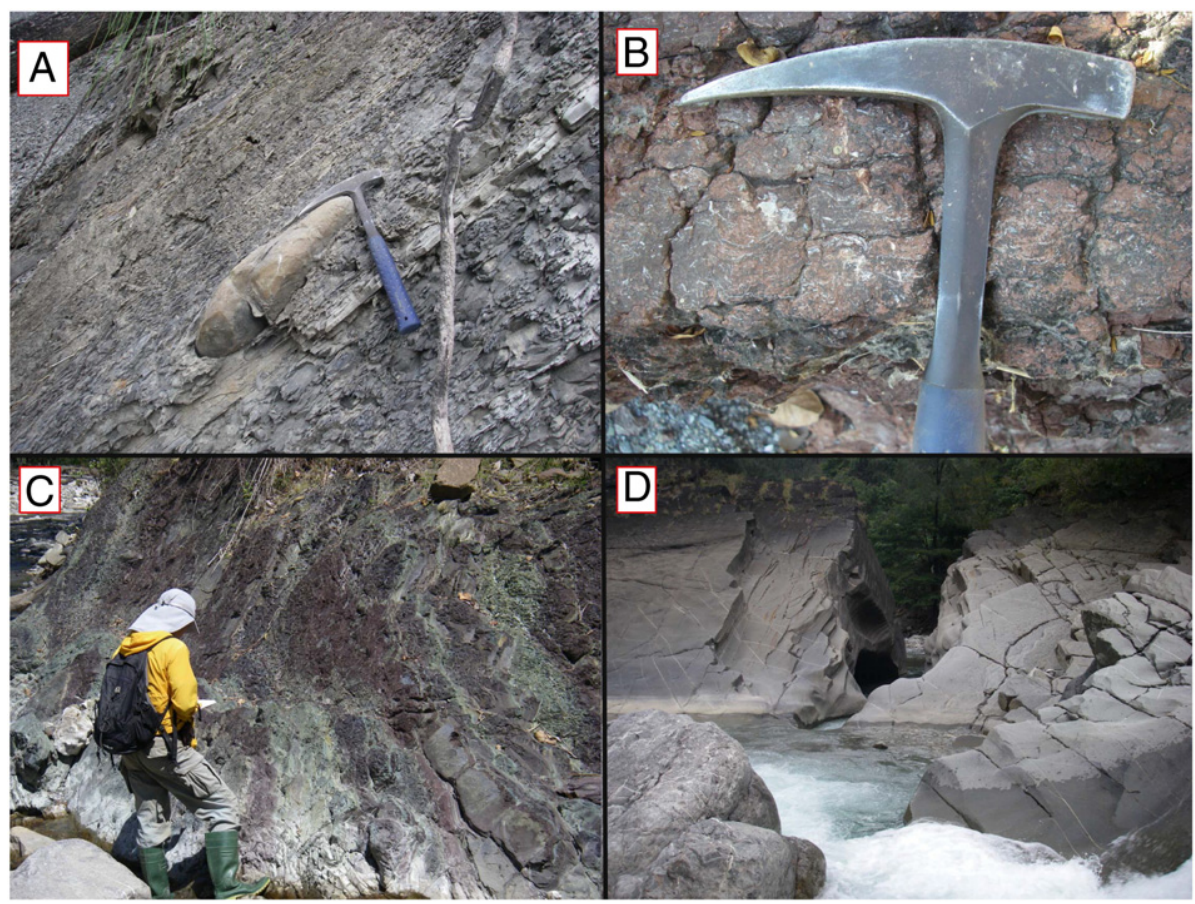

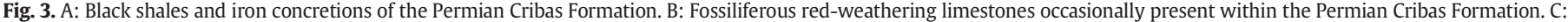
Alternating red and green shales of the Niplelo Member of the Triassic Niof Formation. D: Thick green sandstones of the Triassic Babulu Formation.

zircon (Zobell, 2007; Spencer et al., 2016) analyses indicate that many of these sediments were sourced from terranes to the north of Australia, after which those terranes were rifted away from the Australian margin and accreted to various regions in Southeast Asia. Other detrital zircon analyses have instead attributed a sediment source from eastern Australia (Boger et al., 2016) or mixed sediment sources from both Australia and terranes formerly north of Timor (Zimmermann and Hall, 2016). Our map patterns suggest that the Permian and Triassic successions are each approximately $1 \mathrm{~km}$ thick, consistent with thicknesses of time-equivalent units imaged by seismic reflection profiles in some locations on the Australian shelf (Karig et al., 1987; Snyder et al., 1996).

Seismic reflection data indicate that the modern Australian margin south of the Timor Trough contains numerous normal faults cutting stratigraphy correlative to the Gondwana Sequence (Tripathi et al., 2012; Baillie and Milne, 2014; Saqab et al., 2017). With the notable exception of large extensional basins such as the Vulcan Graben, the

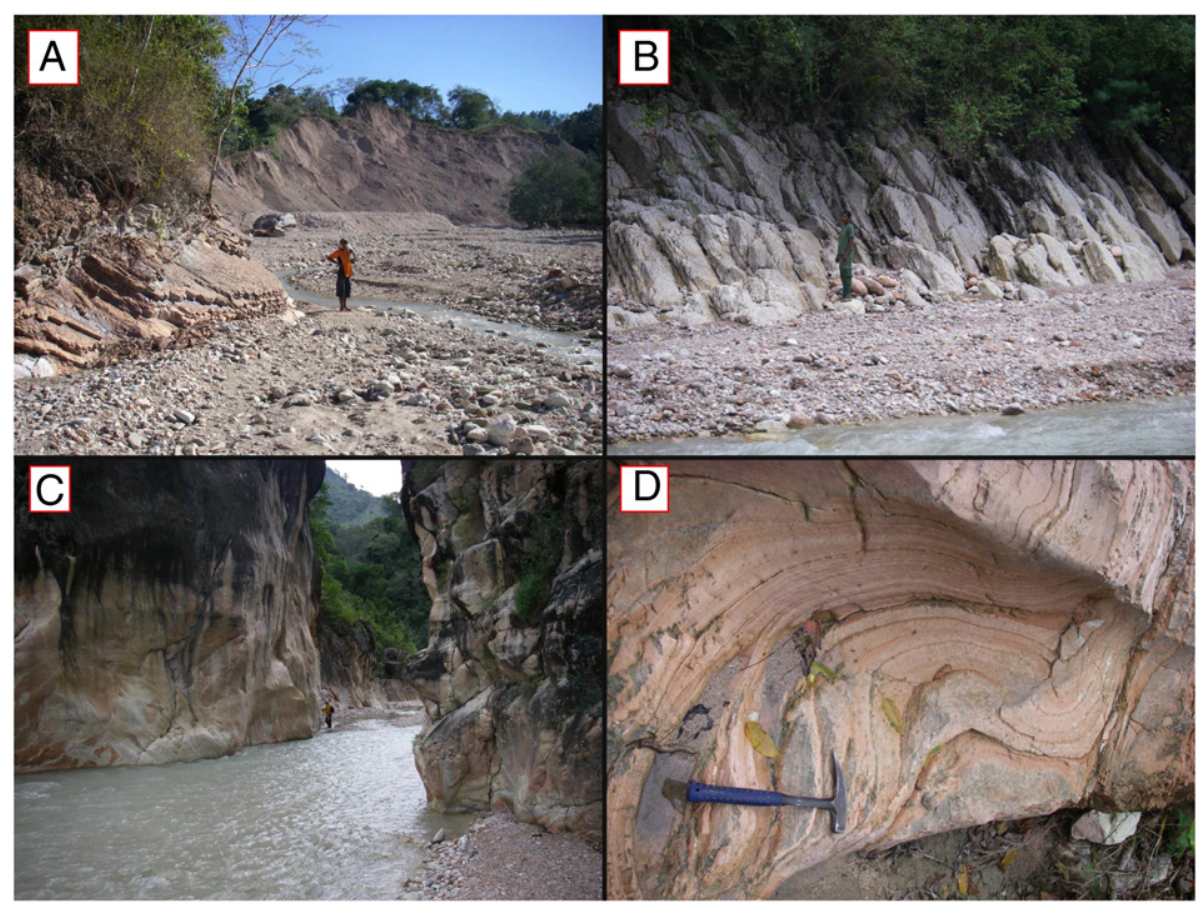

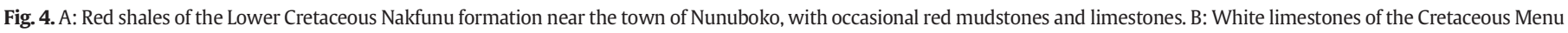
Formation. C: Massive pink and white limestones of the Ofu Formation. D: Folds from soft sediment deformation in the Boralalo Member of the Ofu Formation. 
majority of these normal faults appear to have offset less than the approximately $1 \mathrm{~km}$ stratigraphic thicknesses of each of the Gondwana Sequence units. Additionally, many of these normal faults formed or were reactivated due to flexure during arc-continent collision (Saqab et al., 2017), so we would expect less extension in the pre-collisional margin than is observed today.

\subsubsection{Permian: Cribas, Atahoc and Maubisse Formations}

The Permian stratigraphy of Timor, initially defined in Timor-Leste by Audley-Charles (Audley-Charles, 1968), was described in detail in West Timor by Bird and Cook (1991) and by Charlton et al. (2002). The Lower Permian Atahoc and Upper Permian Cribas Formations in West Timor were originally defined as consisting primarily of shales and sandstones with occasional pillow lavas and limestones and were interpreted as deposits within rift basins near the northern margin of Gondwana (Bird and Cook, 1991). The Permian Maubisse Formation primarily consists of crinoidal carbonates, lavas and volcaniclastic units, interpreted as deposits on higher platforms coeval with basin deposition of the Atahoc and Cribas Formations (Bird and Cook, 1991). Additionally, some lower sections of the Maubisse Formation in Timor-
Leste have been dated as latest Carboniferous in age (Davydov et al., 2013, 2014).

We found the Atahoc and Cribas formations to consist primarily of black and gray shales containing ironstone nodules with occasional medium to coarse quartz-rich sandstones that weather brown and occasional limestone beds approximately $0.5 \mathrm{~m}$ thick (Fig. 3). Some of these limestone beds weather red and contain plentiful crinoids (Fig. 3), very similar to Maubisse Formation limestone beds (although thinner) and the Cribas formation of Timor-Leste (Tate et al., 2015). These characteristic limestones are used to distinguish the Permian formations from Triassic shale-rich formations. Similar to Bird and Cook (1991) we identified ammonite fossils within shales of the Cribas and Atahoc Formations. We found the Maubisse Formation to consist of massive dark gray limestones that weather red and include abundant crinoids as well as volcanic and volcaniclastic deposits. As Bird and Cook (1991) also found, the Maubisse Formation exposed at the surface is not presently in stratigraphic contact with other Gondwana Sequence units. Instead, the Maubisse Formation is mapped as blocks of $\mathrm{m}$ to $\mathrm{km}$ scale within the Bobonaro mélange, especially abundant near Nenas (Fig. 5).

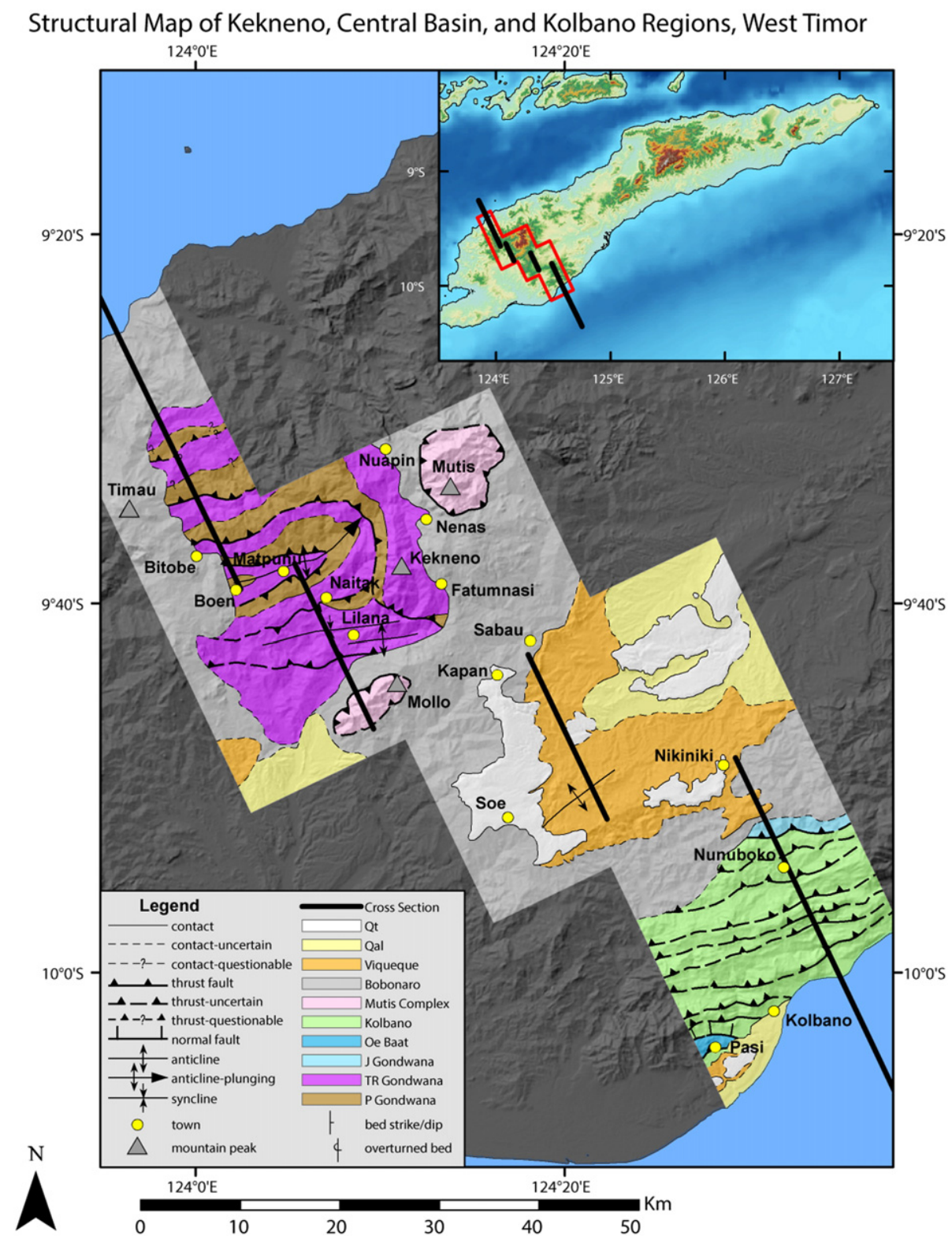

Fig. 5. a: Regional overview map of West Timor structure. b: Structural map of the Kekneno window. c: Structural map of the Central Basin. d: Structural map of the Kolbano range. 


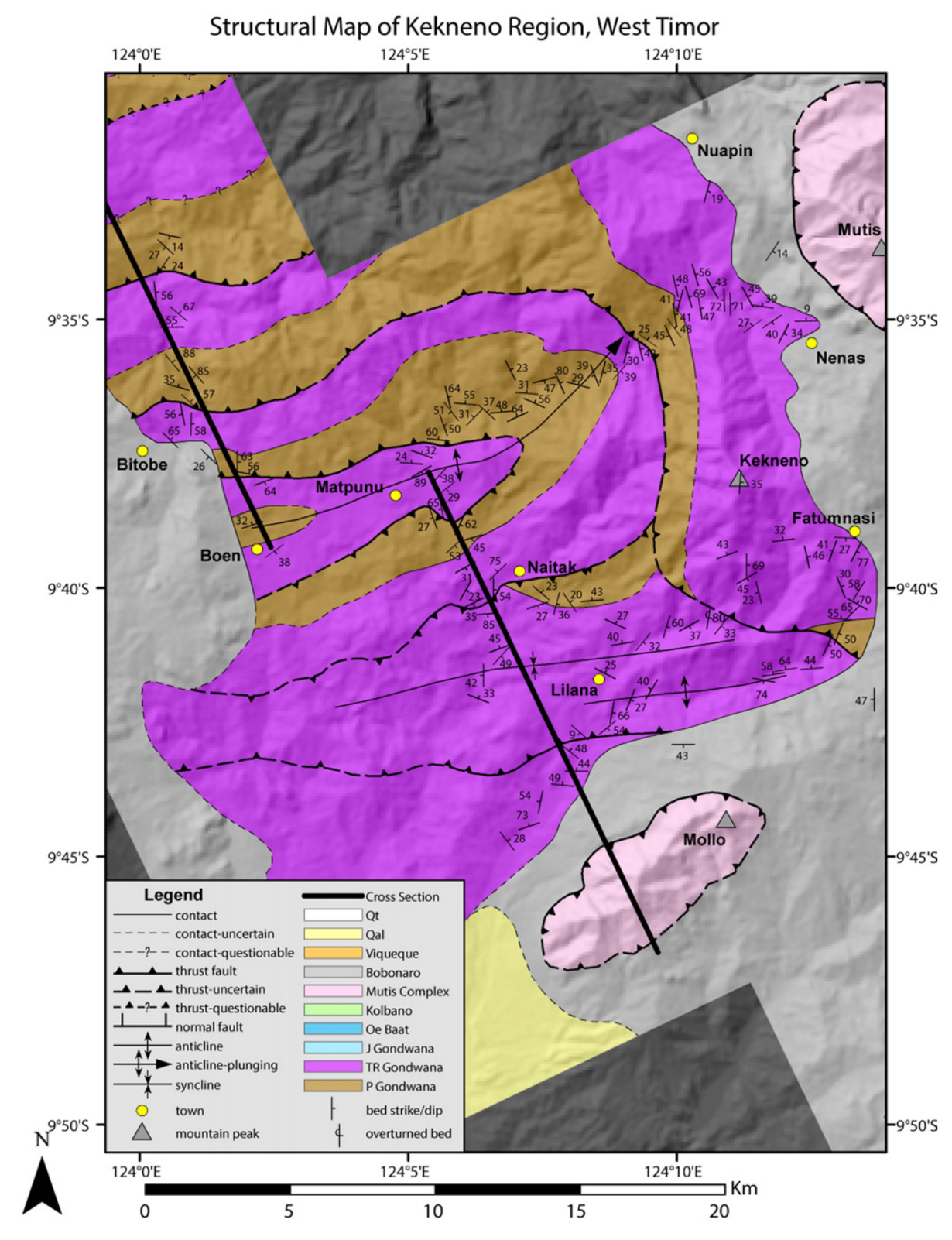

Fig. 5 (continued).

\subsubsection{Triassic: Niof, Babulu and Aitutu Formations}

Previous work has found the Triassic stratigraphy in Timor to be dominated by the Niof and Babulu Formations in West Timor (Bird and Cook, 1991) and by the Aitutu Formation in Timor-Leste (AudleyCharles, 1968). Bird and Cook (1991) divide the Middle Triassic Niof Formation into the Numfuamolo Shale Member (consisting of gray shales, minor sands and occasional slumps and nodule conglomerates) and the Niplelo Shale Member (consisting of red, green and gray shales). The Upper Triassic Babulu Formation has been described as containing greenish sandstones, black to gray micaceous shales, and occasional limestones and marls (Charlton et al., 2009). The Middle to Upper Triassic Aitutu Formation consists of gray, fine calcilutite weathering white with shale interbeds (Audley-Charles, 1968; Tate et al., 2015).

We observed the Numfuamolo Member of the lower Niof Formation to consist of gray shale with occasional limey siltstones and gray limestones. The Niplelo Member of the Niof Formation contains alternating red and green shales and occasional siltstones (Fig. 3). The Babulu Formation is dominated by distinctive green coarse micaceous dirty sandstones sometimes several meters thick (Fig. 3), and also contains micaceous shale and occasional limestone beds. The coarse green sandstones of the Babulu formation were primary targets for thermochronology sampling within the Triassic stratigraphy. The Aitutu Formation consists of $10-15 \mathrm{~cm}$ thick gray limestone beds weathering white with interbeds of 5-10 cm thick shale. Bivalve fossils attributed to Monotis subcircularis were present in Aitutu limestones in several locations. As opposed to Timor-Leste where the Aitutu Formation dominates the Triassic stratigraphy, the Triassic in West Timor typically contained thin sections of the Aitutu Formation facies, only tens of meters, interspersed within the other Triassic units. An exception is the Triassic strata exposed in the southeast corner of the Kekneno window (Fig. 5) that are dominated by the Aitutu Formation.

\subsubsection{Upper Triassic to Jurassic: Wailuli Formation}

The Wailuli Formation has previously been documented to contain gray marls and shales with occasional calcilutites (Audley-Charles, 1968) and has been assigned an age of Late Triassic to Jurassic (Haig and McCartain, 2010). We observed the Wailuli Formation to contain fissile gray shales with occasional fine limestone and sandstone beds. 


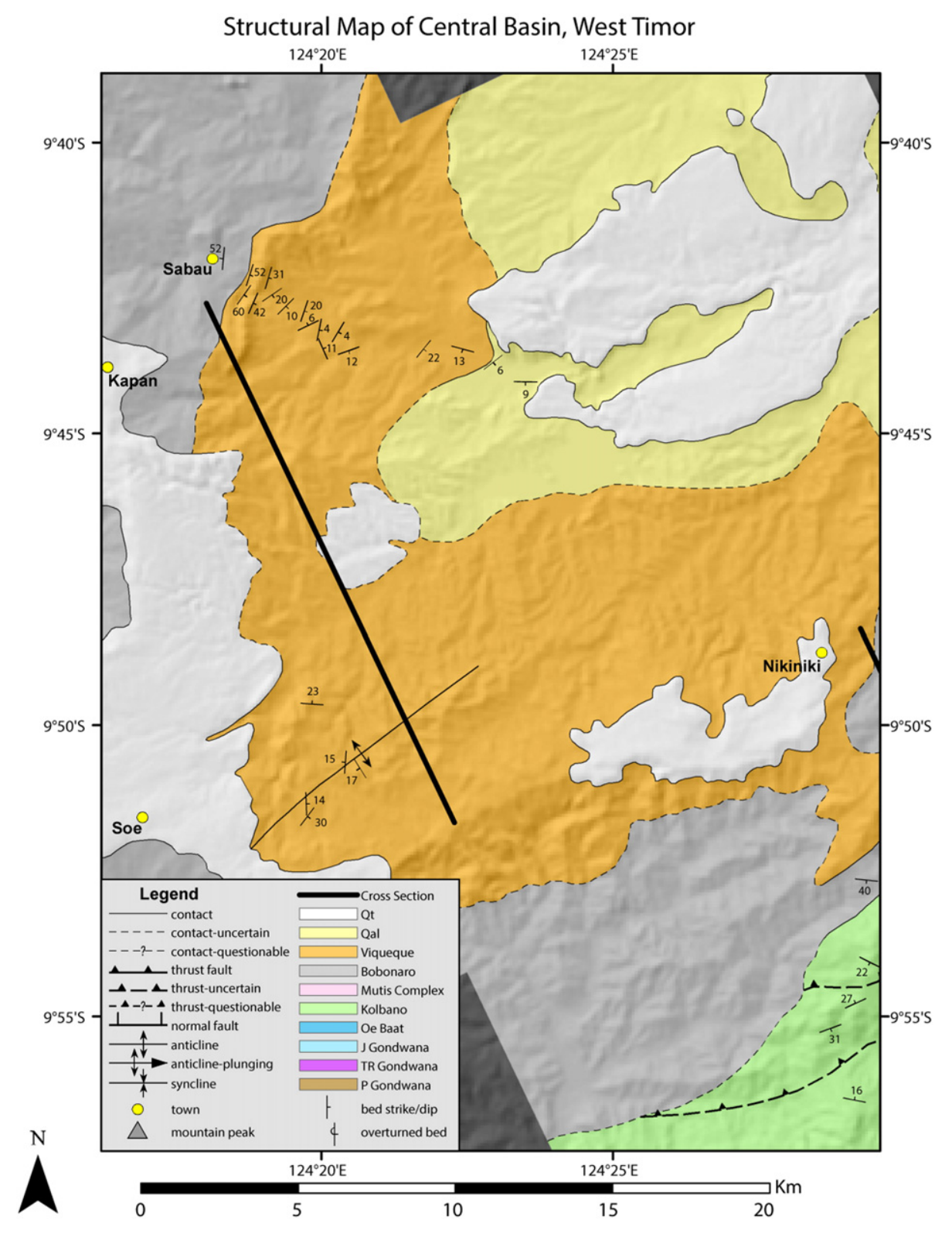

Fig. 5 (continued).

The Wailuli Formation in our map area is found on the north side of the Kolbano range, and highly deformed sections of the Wailuli Formation are occasionally observed within the Bobonaro mélange.

\subsection{Kolbano Sequence}

The stratigraphy of the Kolbano Sequence has been described by Charlton (1989) and in detail by Sawyer et al. (1993). These units have been attributed to the Australian passive margin, deposited after breakup of Gondwana in the Jurassic (Charlton, 1989). Previously measured sections in West Timor (Harris, 2011) and on the island of Rote (Roosmawati and Harris, 2009) found thicknesses of $600-800 \mathrm{~m}$ for the Kolbano Sequence. Our map pattern suggests that the Kolbano Sequence is about $800 \mathrm{~m}$ thick.

\subsubsection{Upper Jurassic OeBaat Formation}

The Jurassic OeBaat Formation was previously described as containing siltstones and shales as well as glauconitic sandstones containing ammonites and belemnites (Sawyer et al., 1993). We found the OeBaat formation to contain medium to coarse green-gray sandstone beds with plentiful belemnites and gray shale. The area near Pasi (Fig. 5) (Charlton, 1989) is the only location that we observed the OeBaat Formation.

\subsubsection{Lower Cretaceous Nakfunu Formation}

Sawyer et al. (1993) described the Lower Cretaceous Nakfunu Formation as containing primarily cherts, calcilutites, claystones and red or gray shales and estimate the thickness of the Nakfunu Formation at $500 \mathrm{~m}$. We found the Nakfunu Formation to be dominated by black and red shales, with some red and white mudstones and some white and pink limestone beds (Fig. 4).

\subsubsection{Lower to Upper Cretaceous Menu Formation}

The Menu Formation has been documented to consist of planar-bedded light red to white calcilutites with bedding thicknesses between 6 and $60 \mathrm{~cm}$ (Sawyer et al., 1993). We described the Menu Formation as 


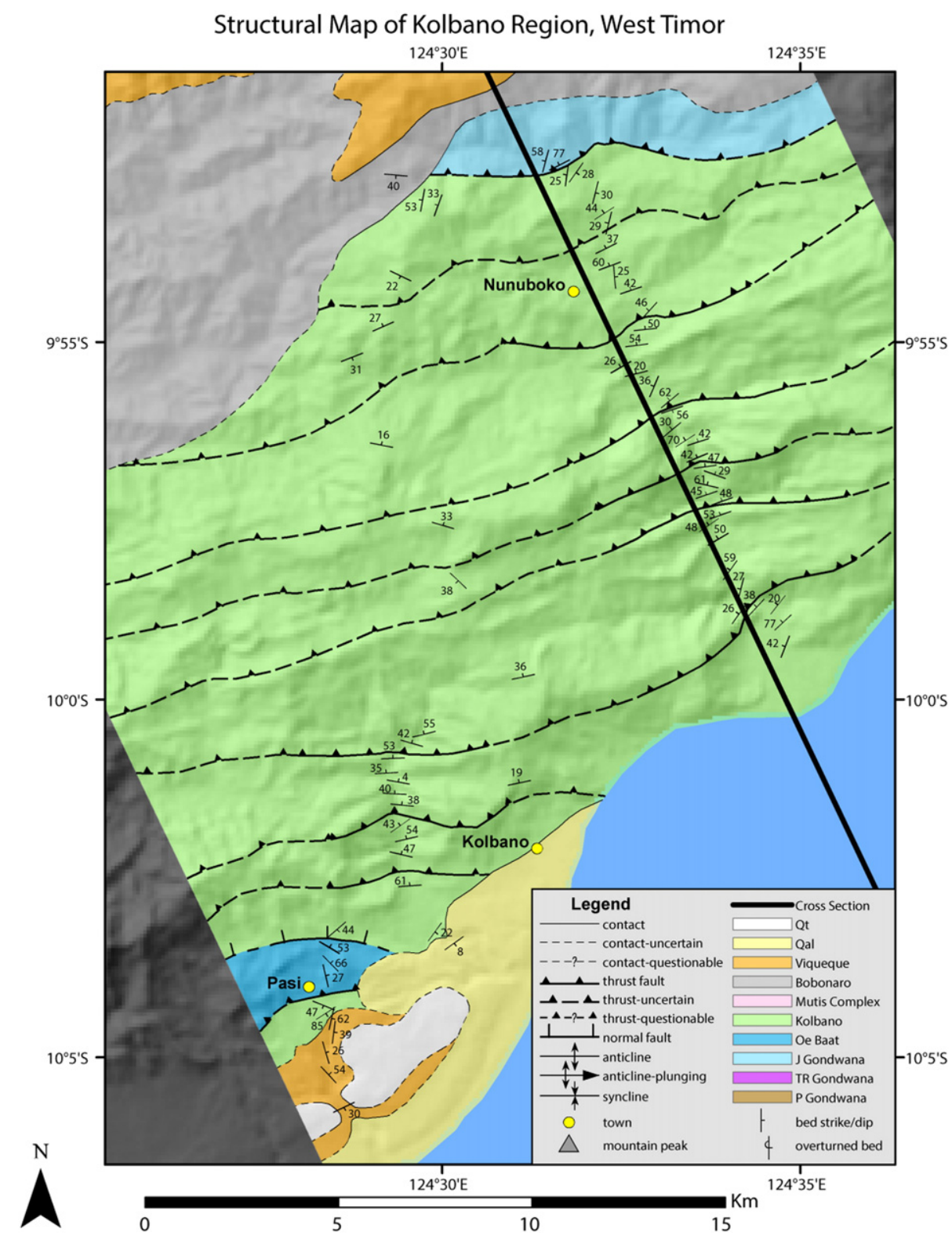

Fig. 5 (continued).

planar-bedded white limestones about $5-50 \mathrm{~cm}$ thick, and we determined that the full thickness of this formation is only approximately $30 \mathrm{~m}$ based on lithostratigraphy (Fig. 4).

\subsubsection{Paleocene to Pliocene Ofu Formation}

The Ofu Formation has been documented to contain three members: the lower Boti Member, the middle Oeleu Member, and the upper Boralalo Member (Sawyer et al., 1993). The Boti Member is described as dominated by white calcilutites either massive or as beds $1 \mathrm{~m}$ thick with wavy bedding planes, as well as chert lenses and rare conglomerates (Sawyer et al., 1993). The Oeleu Member has been described as only $80 \mathrm{~m}$ thick and containing red calcareous mudstones with gray to red calcarenites (Sawyer et al., 1993). The Boralalo Member is described as similar to the Boti Member except that limestones are typically pink and light orange and soft sediment deformation is plentiful (Sawyer et al., 1993). We find the Boti Member dominated by massive and wavybedded white limestones with common chert nodules, the Oeleu Member to contain red and gray $15 \mathrm{~cm}$ thick calcareous mudstones with gray clay interbeds are rare red chert lenses, and the Boralalo to contain pink and red massive and wavy bedded limestone with folds from soft sediment deformation (Fig. 4)

\subsection{Banda Terrane}

The Banda Terrane in West Timor consists predominantly of the Mutis Complex, a package of metamorphosed rock units containing predominately phyllites, chlorite schists, and amphibolite gneiss (Rosidi et al., 1979; Brown and Earle, 1983). The Mutis Complex has been interpreted as equivalent to the Lolotoi Complex of Timor-Leste, and both are interpreted to belong to the forearc of the Banda Arc (Harris, 2006). A Permian age had previously been proposed for both the Mutis Complex (Rosidi et al., 1979) and Lolotoi Complex (AudleyCharles, 1968). However, zircon U-Pb analyses in the Mutis and Lolotoi Complexes yield significantly younger ages of 82-34 Ma (Harris, 2006; Standley and Harris, 2009). We observed the Mutis Complex at Mt. Mutis to contain plagioclase-rich amphibolite, graphite and chlorite schist, and phyllite. We did not map other previously-documented volcanic and sedimentary Banda Terrane units in our map area except for 
blocks of the Paleocene - Eocene Dartollu Limestone (Harris, 2006) as blocks within the Bobonaro mélange near Mt. Mutis.

\subsection{Banda Orogen Sequence}

The Banda Orogen Sequence refers to those units that were deposited on the Timor orogenic wedge or that were formed during orogenesis between Australia and the Banda Arc (Roosmawati and Harris, 2009).

\subsubsection{Bobonaro mélange}

The Bobonaro mélange has been documented as a tectonic mélange occupying the structural position between underplated Australianaffinity units and overthrust Banda Terrane units (Harris et al., 1998). This mélange has a shale matrix sourced from the Wailuli Formation surrounding $\mathrm{m}$ - to km-scale blocks of all other unit types (Harris et al., 1998). We observed the Bobonaro mélange as a gray shale matrix containing $\mathrm{m}$ - to km- scale blocks, with large blocks of Maubisse Formation and ultramafic rocks especially prevalent near Fatumnasi (Fig. 5). We mapped this mélange as structurally between the Gondwana Sequence and the Mutis Complex, in structural contact with the northern side of the Kolbano range, and below the Viqueque Sequence and younger synorogenics in the Central Basin.

\subsubsection{Viqueque Sequence}

The Viqueque Sequence comprises the earliest synorogenic sedimentary strata deposited on Timor. This sequence has been described as a succession of deepwater deposits, with a basal unit of primarily chalky pelagic limestones and marls known in Timor-Leste as the Batu Putih Formation overlain by a sequence of clays, turbidites, sandstones and conglomerates (De Smet et al., 1990; Haig and McCartain, 2007; Tate et al., 2014).

Basal Viqueque Sequence units in our map area are deposited directly on the Bobonaro mélange. This stratigraphic relationship necessitates designating the Viqueque Sequence as a synorogenic sequence despite the low-energy depositional environment of the basal pelagic units; the Bobonaro mélange was developed as a tectonic mélange during orogenesis at Timor, so it follows that basal Viqueque Sequence deposition must have begun after the start of structural deformation at Timor. The Mutis Complex or Kolbano Sequence (which typically structurally overlie the Bobonaro mélange) are absent between the Viqueque Sequence and the Bobonaro mélange in our map area. This requires some mechanism of bringing the mélange to the seafloor before depositing the Viqueque Sequence. One possible explanation is removal of the Kolbano Sequence by gravitational sliding along a tilted Bobonaro mélange detachment, as proposed in Timor-Leste (Tate et al., 2014). Similar gravitational sliding has been demonstrated for the $2 \mathrm{~km}$ thick Lycian Nappes in Turkey (van Hinsbergen, 2010). Alternatively, the Bobonaro mélange may have been emplaced above the Kolbano thrust stack via diapirism (Barber et al., 1986; Harris, 2011).

Our detailed stratigraphic observations of the Viqueque Sequence in the Central Basin are included in Section 5. We also map the occurrence of Viqueque Sequence deposits on the south coast, south of Pasi.

\subsubsection{Younger synorogenics}

Synorogenic deposits of the Banda Orogen Sequence also include coral terraces, shallow marine deposits and alluvial gravels (Roosmawati and Harris, 2009). We observed coral terraces as white limestone that weather black with preserved coral textures in hand sample. These terraces are found in several locations across the Central Basin to elevations up to $1100 \mathrm{~m}$. They are mapped as unconformably overlying the Viqueque Sequence and associated shallow marine deposits. While most plentiful in the Central Basin, the younger synorogenic deposits are also found in our map area in a narrow strip along the south coast and in the river basin south of the Kekneno window.

\section{Structural mapping}

\subsection{Mapping methods}

Field mapping was conducted at a scale of 1:50,000. GPS in the WGS 1984 reference frame was used for location. Mapping was focused along a single transect of West Timor in three main areas: the Kekneno window, the Central Basin, and the Kolbano range (Fig. 5a-d). In Fig. 5b-d, strike and dip measurements and solid contacts and faults indicate those areas that were visited. Mapping in the Kekneno window was performed mostly along riverbeds, focusing on the river from Nenas to Lilana, one river south of Lilana and its two forks to the east toward Fatumnasi, one river section near Boen and one river flowing to the north from Bitobe (Fig. 5b). Roadcuts north of Lilana and the trail up Mt. Kekneno were also used in mapping the Kekneno window (Fig. 5b). Roadcuts between Lilana, Kapan, Fatumnasi, Nenas and Nuapin allowed for observations of the Bobonaro mélange around the window, and the trail up Mt. Mutis allowed for observations of the Mutis Complex (Fig. 5a). Observations in the Central Basin were gathered from a river transect in the Sabau section of the Viqueque Sequence, along roadcuts on small roads in the Viqueque Sequence east of Soe, and along roadcuts between Kapan, Soe and Nikiniki (Fig. 5c). Mapping in the Kolbano Range relied primarily on riverbed observations in the river just east of Nunuboko, a river flowing south of Pasi and another river between these two (Fig. 5d). Roadcuts between Nikiniki and Kolbano and around Pasi supplemented the Kekneno Range observations (Fig. 5a).

\subsection{Kekneno window}

Previous mapping in the Kekneno window showed structural repetition of the Permian and Triassic Gondwana Sequence (Rosidi et al., 1979; Bird and Cook, 1991). In one area of the window, Rosidi et al. (1979) map a large northeast-striking anticline of a single succession of Permian and Triassic units, with the main antiform axis north of our Kekneno map area. Such a large anticline, with indicated limb dips of $45-60^{\circ}$, would require unit thicknesses for the Gondwana Sequence much thicker than previously described. Rosidi et al. (1979) also show three thrust faults striking approximately E-W on the southern side of the window. In the Rosidi et al. (1979) map, exposure of Permian strata in the thrust slice at Lilana with the Permian-Triassic contact truncating against the thrust fault at Naitak suggest a preserved hanging wall cutoff in map pattern (similar to our mapped fault at Naitak in Fig. 5b), although the vergence direction of their mapped fault shows this apparent hangingwall cutoff in the footwall of the fault. Bird and Cook (1991) map a portion of the Kekneno window north of Naitak as a sequence of thrust repetition of Permian and Triassic strata. The thrusts and contacts mapped by Bird and Cook (1991) all strike approximately E-W, with numerous strike-slip faults striking approximately north-south crosscutting this thrust stack. Unit strikes indicated by Bird and Cook (1991), however, are frequently perpendicular to the strike of thrusts and contacts, most notably just west of Nenas where those authors described the type sections defining the stratigraphy of the Niof Formation.

We mapped a structural repetition of the Permian to Triassic Gondwana Sequence stratigraphy in the Kekneno window (Fig. 5b, Fig. 6). Bobonaro mélange is found structurally above these deformed Gondwana Sequence strata on all sides of the window, with klippen of the Mutis Complex visible structurally above the Bobonaro mélange at Mt. Mutis to the east and Mt. Mollo to the south. The structural repetition mapped here is consistent with an antiformal stack, and critical points in support of this are discussed in the following paragraph, first in the center of the Kekneno window near Matpunu, then in the southern part of the window near Naitak and Lilana, then in the eastern area near Nenas and Mt. Kekneno, and lastly in the northern part of our mapped area north of Bitobe. 


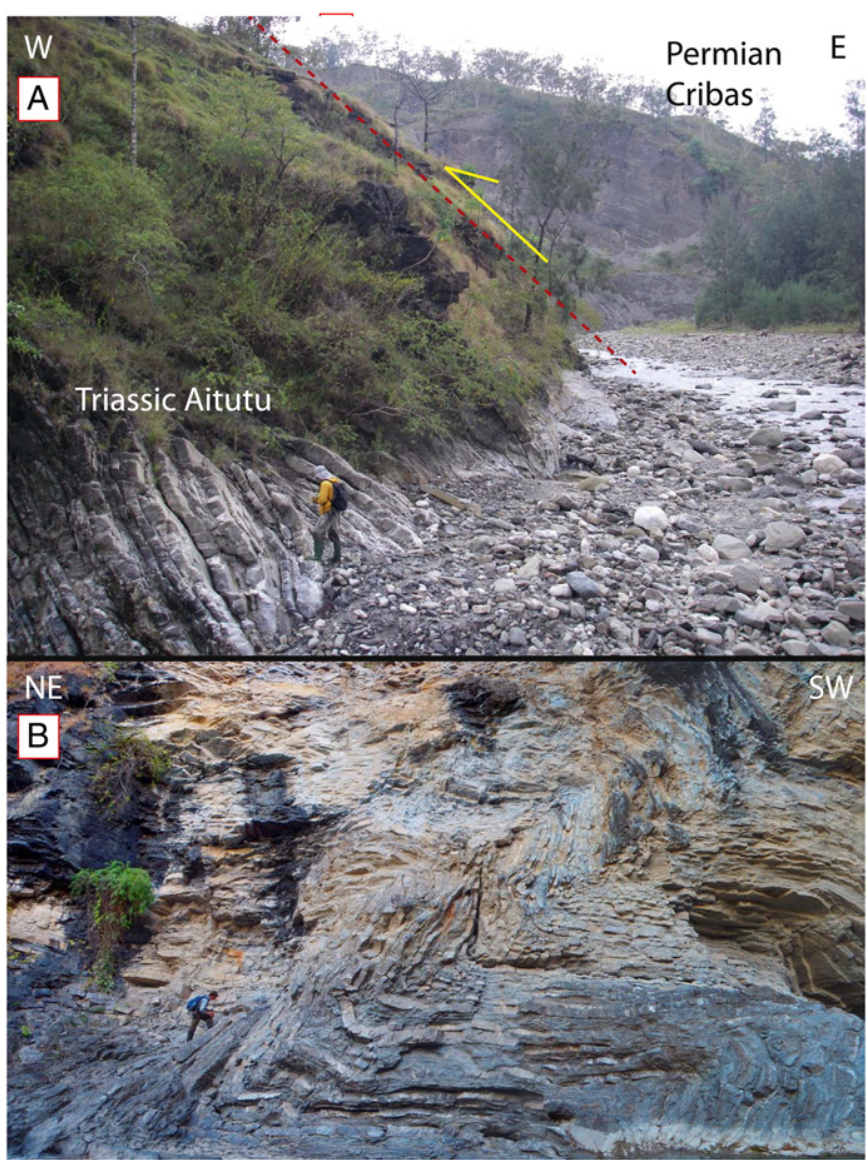

Fig. 6. A: Thrust of east-dipping Permian Cribas Formation (background) above eastdipping Triassic Aitutu Formation (foreground) to the west of Nenas. B: Southwestverging folds within the Aitutu Formation in the footwall of the thrust fault adjacent to the town of Naitak. Fold vergence confirms fault motion toward the foreland and subsequent tilting to current fault dip toward the south.

In the center of the deformed Gondwana Sequence region is an ENEplunging anticline axis. This anticline axis is the center of an antiformal stack in map pattern, with this plunging anticline folding two thrust faults and the repeated the Permian-Triassic stratigraphy between those faults. A mud volcano is present along this anticline axis near the town of Matpunu, containing clasts of Babulu sandstones. A thrust fault south of the antiform axis at Naitak is found to have its hangingwall on the south side of the fault, but fold vergence toward the south in the footwall (Fig. 6) suggests that motion along this thrust was toward the south (consistent with the tectonic transport direction) and that this thrust has subsequently been folded by the antiform. A preserved hanging wall cutoff map pattern is found truncating against this fault at Naitak, consistent with previous mapping (Rosidi et al., 1979). An Estriking syncline at Lilana separates this folded south-dipping thrust with a north-dipping thrust in the southern area of the window. Another Permian-Triassic sequence is found at Mt. Kekneno and Nenas, with a preserved hangingwall cutoff mapped at the thrust found along the base of Mt. Kekneno. West of Nenas and along the antiform axis, Gondwana Sequence units strike N-S and dip to the east (consistent with previous mapping (Bird and Cook, 1991)), showing that the antiform structure plunges east below the Bobonaro mélange at Nenas. In the river flowing north of Bitobe, three more sequences of Permian-Triassic stratigraphy are found repeated by thrust faults. The southernmost (lowest) of these three sequences is mapped as possibly contiguous with the stratigraphy at Nenas and Mt. Kekneno, but this has not been confirmed in the field. The final repetition mapped here is shown as questionable, and has only been mapped with aerial photography.

\subsection{Central Basin}

Previous mapping in the Central Basin indicated exposure of the Viqueque Sequence and Quaternary deposits directly on the Bobonaro mélange, with limestone terraces unconformably overlying all these units (Rosidi et al., 1979). In addition, several fold axes and normal faults have been mapped within the Central Basin (Rosidi et al., 1979).

We mapped the Central Basin in the region between Kapan, Soe and Nikiniki, with observations generally consistent with the map pattern of Rosidi et al. (1979) (Fig. 5c). The map pattern of this basin is that of a very broad ENE-plunging syncline with synorogenic sediments unconformably overlying the Bobonaro mélange on both the northern and southern sides of the basin. Alluvial and shallow marine deposits are found in the northeast corner of the mapped part of the basin, with Viqueque Sequence dominating exposure on the southern and western sides of the mapped basin. Coral terraces unconformably overlie the Bobonaro mélange, the Viqueque Sequence and the Quaternary alluvium. Mapped fold axes in the Viqueque Sequence indicate folding after deposition with limbs dipping $14-30^{\circ}$.

\subsection{Kolbano range}

Previous mapping of the Kolbano range by Rosidi et al. (1979) indicated that the majority of this range consisted of a thrust stack repeating a succession of Ofu Formation and Batu Putih Formation, with two thrust sheets of Nakfunu Formation at the northern edge of the Kolbano Range. Later, more detailed mapping by Sawyer et al. (1993) revealed a thrust stack that did not include the Batu Putih Formation of the Viqueque Sequence, but rather was dominated by a thrust stack of Cretaceous to Pliocene Kolbano Sequence units. Mapping by Sawyer et al. (1993) also indicated that the northernmost thrust sheets of the Kolbano range exposed only the Nakfunu Formation at the surface, that the Jurassic Wailuli Formation is thrusted over the Kolbano stack north of Nunuboko, and that the Wailuli Formation was exposed at the base of the Kolbano Sequence in the first thrust sheet south of Nunuboko (Fig. 5d). Previous mapping by Harris (2011) in the Kolbano area interpreted an imbricate thrust stack repeating a Cretaceous to Pliocene section 19 times, and a $13 \mathrm{~km}$-long balanced cross section accompanying that previous mapping yielded 58\% shortening (with pressure-solution cleavage indicating additional unconstrained shortening). Both Charlton (1989) and Sawyer et al. (1993) documented the occurrence of the Jurassic OeBaat Formation at Pasi (Fig. 5), bound to the north and south by the Ofu Formation. Sani et al. (1995) document the continuation of the Kolbano thrust stack offshore for $50 \mathrm{~km}$ to the deformation front. Well penetration confirms that the basal detachment of the imbricate stack is along the Wailuli Formation (Sani et al., 1995).

Our mapping of the Kolbano range (Fig. 5d), is in good agreement with mapping by Sawyer et al. (1993). Linear ridges of the Kolbano range tend to follow resistant massive limestone lithologies in each thrust sheet. Along the cross section trend at Nunuboko six thrust faults within the Cretaceous-Pliocene Kolbano Sequence are mapped, in addition to one thrust at the northern end of the Kolbano Range that thrusts Jurassic Wailuli Formation over the Lower Cretaceous Nakfunu Formation. Thrust sheets along this section expose increasingly deeper stratigraphy to the north: the hanging walls of the southern three thrusts (immediately north of the shoreline) along this section only expose a very thin portion of the Lower Cretaceous Nakfunu Formation adjacent to the fault, while the hangingwall of the fourth thrust upstream exposes the full Cretaceous-Pliocene Kolbano Sequence stratigraphy at the surface and the two northernmost Kolbano Sequence thrust sheets expose only the Nakfunu formation at the surface. In the western Kolbano range map area (Fig. 5d) three more thrust faults within the Kolbano range are visible to the south onshore. The thrust sheet at Pasi contains the Jurassic OeBaat Formation, bound by a normal fault to the north and a thrust fault to the south. 


\section{Synorogenic basin micropaleontology}

\subsection{Stratigraphy}

A sedimentary log of the Sabau section of the Central Basin is presented in Fig. 7. At the base, chalky marls are deposited unconformably on the Bobonaro mélange. The basal unit contains well-bedded chalky marls, white limestones, and occasional tuffs (Fig. 8). At $48 \mathrm{~m}$ is an erosional unconformity at the base of a unit of coarse clastics, which is a sequence of lithic coarse sandstones, pebble conglomerates, and fine sandstones, all interpreted as mass-flow deposits (turbidites and debris flows), and rare clay layers. Erosional truncations and angular unconformities (Fig. 8) are common between sandstone beds. Conglomerates contain clasts of quartz, red limestone and serpentinite. Large slump folds are present within this unit as well (Fig. 8). At $171 \mathrm{~m}$ from the base begins a unit consisting primarily of clays. No unconformity is observed at the base of this unit, but one is suggested by a sharp change in the strike and dip of units. Clays with occasional silts and sands continues to $288 \mathrm{~m}$ from the base of the section, where a unit of interbedded turbiditic sandstones and clays begins (Fig. 8). This unit is overlain beginning at $415 \mathrm{~m}$ by shallow marine deposits, consisting of gray cross-bedded sands and cobble and pebble conglomerates.
Conglomerates contain clasts of quartz, gray and red limestone, and serpentinite, and in some cases cut into underlying strata in erosional channels. A number of unexposed intervals are found within the clay, turbiditic sandstone and clay, and shallow marine units. Logging of the Sabau section ended at $449 \mathrm{~m}$ above the base. Previous mapping and the mapping presented here indicate that these shallow marine deposits continue above $449 \mathrm{~m}$ and are overlain by shallow marine limestone terraces.

\subsection{Micropaleontology methods}

Samples for foraminiferal micropaleontology were taken from chalky marls and limestones within the basal Batu Putih unit and from clays within the other units (or silts where clays were not available for an extended portion of section). Samples were disaggregated in water, sieved and the $600-125 \mu \mathrm{m}$ fraction was used for foraminiferal analysis. Planktonic foraminifera are used for age control, while benthic foraminifera are used to determine paleobathymetry. Detailed foraminiferal data are available in the supplementary material. Subsequently, washed residues from five samples within the chalks unit were examined for calcareous nannofossils to provide further age control.

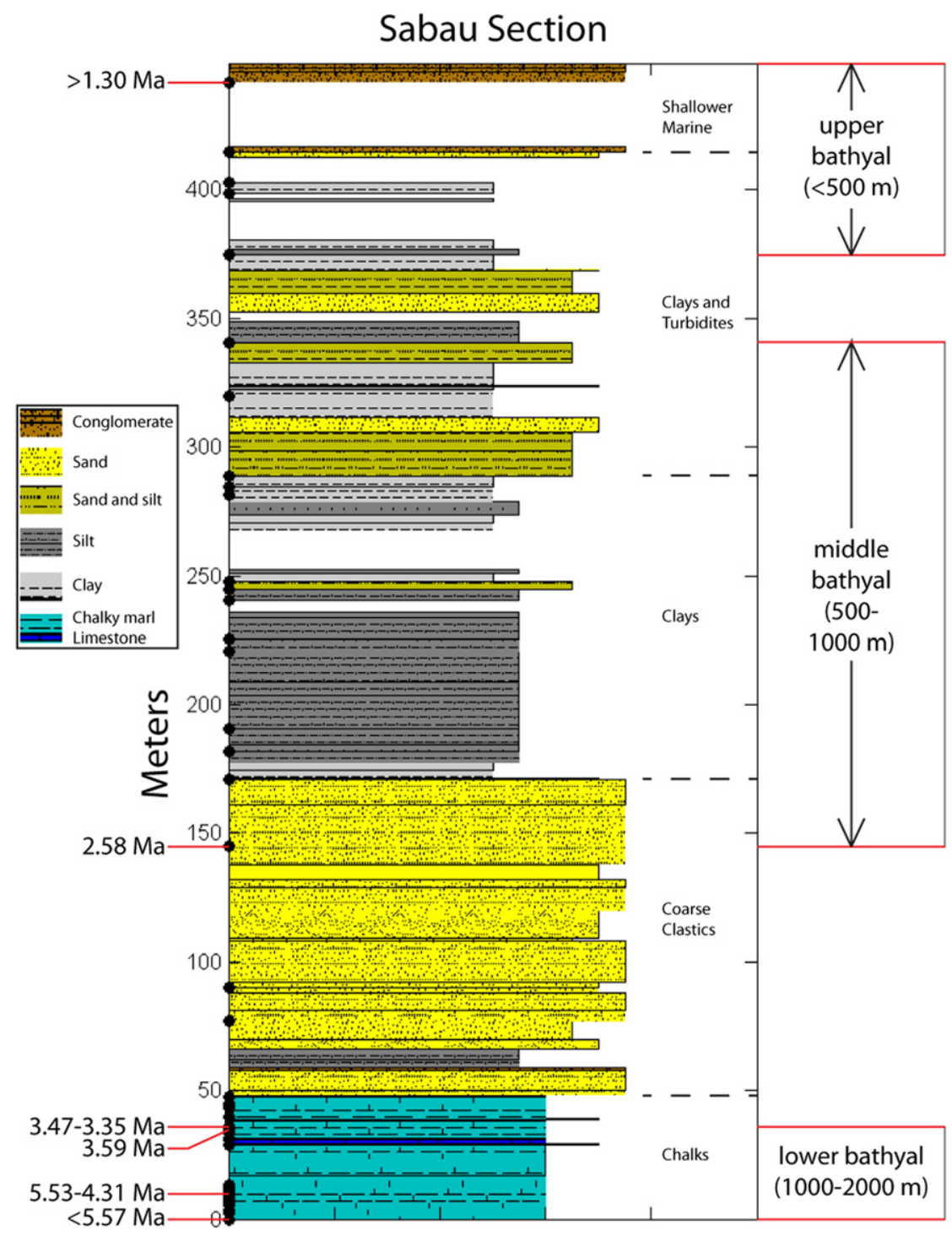

Fig. 7. Sedimentary log of the Sabau section, including age and depth constraints from foraminiferal micropaleontology. Intervals labeled with a range of ages indicate hiatuses. 


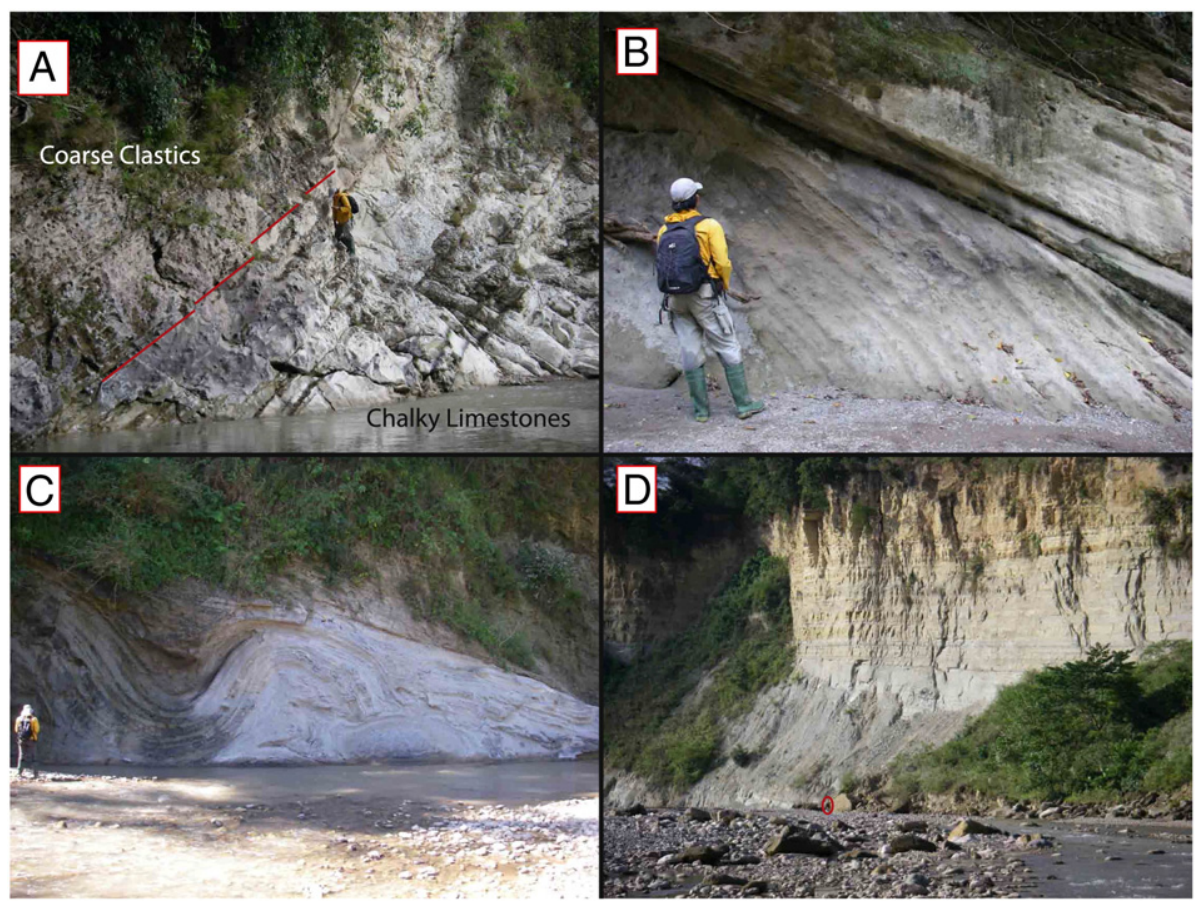

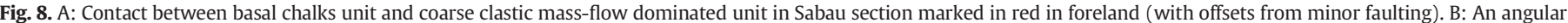

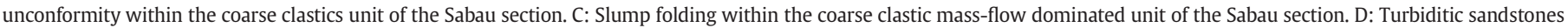
and clays within the Sabau section. Person at cliff base circled for scale.

\subsection{Age control}

Between the base and $9 \mathrm{~m}$ above the base, the presence of Sphaeroidinellopsis and Globorotalia tumida and the absence of Sphaeroidinella dehiscens indicate a latest Miocene age of 5.57-5.53 Ma (Lourens et al., 2004). Relatively few foraminifers with variable but generally poor preservation could be disaggregated from the cemented chalks, so several rectangular picking trays $(11 \times 7 \mathrm{~cm})$ were surveyed to examine sufficient numbers of Sphaeroidinellopsis. No evolutionarily advanced forms of Sphaeroidinellopsis having a supplementary aperture were found. Such advanced forms would belong to Sphaeroidinella dehiscens and first occur at 5.53 Ma (Lourens et al., 2004), providing a minimum age bound for the lowest $9 \mathrm{~m}$ of the section. We do not consider it likely that these species were reworked considering the lowenergy depositional environment, the absence of any species clearly older than $5.57 \mathrm{Ma}$ or younger than $5.53 \mathrm{Ma}$, and the lack of sorting in species sizes. As an additional check on the latest Miocene age we sent four washed residues to Isabella Raffi (University of Chieti-Pescara, Italy) for calcareous nannofossil biostratigraphy. Calcareous nannofossil associations, captured after crushing and soaking residues in water, were dominated by unusual numbers of Sphenolithus specimens. The late Miocene marker Discoaster berggrenii in the basal sample and the absence of Reticulofenestra pseudoumbilicus and Amaurolithus primus in all four samples suggest a minimum age range of 8.2-7.4 Ma (zones CNM16 and 17, see Backman et al., 2012) and a maximum age range of 8.2-5.53 Ma for the basal $9 \mathrm{~m}$ (I. Raffi, pers. comm. 2014). The minimum age range is likely too old because of the presence of the planktonic foraminifer Pulleniatina primalis (first occurrence at 6.6 Ma, Wade et al., 2011). The calcareous nannofossils thus confirm the late Miocene age estimate but in this case planktonic foraminifers provide the narrowest age range for the basal $9 \mathrm{~m}$, that is, 5.57-5.53 Ma.

The simultaneous appearance at $10.5 \mathrm{~m}$ of Sphaeroidinella and Globorotalia crassaformis suggests a hiatus from 5.53 to $4.31 \mathrm{Ma}$ (Lourens et al., 2004; Wade et al., 2011) between 9 and $10.5 \mathrm{~m}$. The calcareous nannofossil assemblage with Discoaster pentaradiatus and
Pseudoemiliania lacunose and absence of Reticulofenestra pseudoumbilicus at $10.5 \mathrm{~m}$ (I. Raffi, pers. comm. 2014) suggests an age of about 3.6 Ma (Backman et al., 2012), allowing the possibility that this hiatus is even longer.

The last common occurrence of Sphaeroidinellopsis is found at $35 \mathrm{~m}$. The age of 3.59 Ma for this bioevent in the Pacific (Lourens et al., 2004) is consistent with the stratigraphic order here. The few small-sized and cortified specimens without supplementary aperture that co-occur with Sphaeroidinella dehiscens at $39.5 \mathrm{~m}, 45 \mathrm{~m}$ and $47.5 \mathrm{~m}$ are considered juveniles of the nominate taxon.

The last occurrence of Globoquadrina altispira and first occurrence of Globorotalia tosaensis suggests a small hiatus from 3.47 to 3.35 Ma between 35 and $36 \mathrm{~m}$ (Lourens et al., 2004; Wade et al., 2011). The hiatus between 35 and $36 \mathrm{~m}$ is confirmed by the change-over from rare and small-sized Neogloboquadrina acostaensis-humerosa to common and larger sized Neogloboquadrina dutertrei.

The first keeled representatives of Globorotalia tosaensis are observed at $145 \mathrm{~m}$ and should per definition be assigned to Globorotalia truncatulinoides. The evolution of this keeled species from the ancestral and non-keeled Globorotalia tosaensis is (in the Pacific) dated at $2.58 \mathrm{Ma}$ (Gradstein et al., 2012). Globorotalia truncatulinoides remains spotty and rare up to $341 \mathrm{~m}$ but becomes more persistent above this level albeit that overall numbers of this species and the ancestral Globorotalia tosaensis are low (see Supplementary material).

Sporadic and small-sized Globigerinoides obliquus are found up to the top of the section, suggesting that the top of the section is older than 1.30 Ma (Lourens et al., 2004).

\subsection{Paleobathymetry}

Lower bathyal species characteristic of depths from 2000 to $1000 \mathrm{~m}$ dominate from the base of the section to $36 \mathrm{~m}$ within the chalks unit, including Pullenia bulloides, Pullenia quinqueloba, Gyroidina orbicularis, Melonis soldani, Karreriella bradyi, Oridorsalis umbonatus, and Cibicides wuellerstorfii (Van Marle, 1989, 1991). 
Mixtures of shallow and deeper water species above $36 \mathrm{~m}$ point to downslope transport. Particularly for the species that are neither truly shallow nor deep, displacement may influence any paleodepth reconstruction: their co-occurrence with lower bathyal species indicates either lower bathyal depths if they are displaced by turbidity currents or lower middle bathyal depths if they are in situ. The problem of downslope transport of benthic foraminifers by turbidity currents is smallest in the clay samples. In clay samples at $145 \mathrm{~m}$ and $171 \mathrm{~m}$ within and at the top of the coarse clastics unit, typically middle bathyal (1000$500 \mathrm{~m}$ depth) species Hyalinea balthica and Cassidulina crassa (Van Marle, 1989) are mixed with typically lower bathyal species (Pullenia bulloides, Melonis soldanii, Cibicides wuellerstorfi and Cassidulina carinata (Van Marle, 1988)) and species occupying middle to lower bathyal depths (hispid and costate uvigerinids (Van Marle, 1988)). If these middle bathyal species are in situ then a depositional depth of $\sim 1000 \mathrm{~m}$ is a fair estimate for these levels. The regular occurrences of pteropods above $145 \mathrm{~m}$ and absence below $145 \mathrm{~m}$ suggest that the Sabau site became uplifted to above the aragonite compensation depth around the $145 \mathrm{~m}$ level. At $288 \mathrm{~m}$ (the top of the clays unit), pristine preservation suggests an in situ benthic fauna to which epiphytes (including Amphistegina, Hanzawaia boueana, Cibicides refulgens, and Cibicides lobatulus) are admixed by rafting. The autochthonous component is a mixture of typically middle bathyal species (exemplified by Sphaeroidina bulloides, Hyalinea balthica, and Bolivinita quadrilatera (Van Marle, 1988, 1991)) and lower bathyal ones (including Pullenia bulloides, Cassidulina carinata, Cibicides wuellerstorfi, Cibicides bradyi, and Melonis affinis (Van Marle, 1988)). This mixture, supplemented by species occupying both middle and lower bathyal depths (Bulimina alazanensis, and costate and hispid uvigerinids (Van Marle, 1988)), is indicative of lower middle bathyal depths of 750-1000 m (Van Marle, 1988; van Hinsbergen et al., 2005).

Lower and middle bathyal species remain present up to and including the sample at $341 \mathrm{~m}$. Higher samples beginning at $375 \mathrm{~m}$ contain few and rare middle bathyal species in combination with typically upper bathyal (<500 $\mathrm{m}$ depth) or shelf species (including the nonepiphytic Asterorotalia gaimardii, Cibicides dutemplei, and Cibicides ungarianus (Van Marle, 1988, 1991)), which if in situ, suggest that the uppermost part of the Sabau section was deposited in or close to the upper bathyal zone. The planktonic foraminiferal fauna remains diverse to the top of the section (including deep-dwelling species) likely indicating depths of $>100 \mathrm{~m}$.

\subsection{History of the Central Basin}

The first sediments that unconformably overlie the Bobonaro mélange are low-energy deepwater deposits of the basal Batu Putih unit with an age of 5.57-5.53 Ma and lower bathyal benthic foraminifera (Fig. 7). Uplift at the location of the Sabau section from lower bathyal ( 1 to $2 \mathrm{~km}$ ) to middle bathyal ( $1 \mathrm{~km}$ to $750 \mathrm{~m}$ ) depths is documented to be sometime between 3.35 and $2.58 \mathrm{Ma}$, at some point in the section between the upper portion of the chalks unit and the upper portion of the coarse clastics unit. This phase of uplift in the region of the Sabau section is consistent with the stratigraphy of the mass flow deposits of the coarse clastic unit, which shows a proximal sediment source provided by an emergent orogen and multiple events of folding/tilting of the basin. The transition from coarse clastics to the clay unit is after $2.58 \mathrm{Ma}$. This lithologic change is likely not due to a subsidence-driven change in depositional environment, as middle bathyal foraminifera persist throughout the clays unit. Rather, the change in depositional environment could be due to a lateral shift of the depocenter of coarse clastics (as with an evulsing channel) or to a change in the location of active uplift in the source terrane. Further uplift at the Sabau section to upper bathyal depths is documented within the turbidites and clays unit between 2.58 and 1.30 Ma. The transition from predominantly clays to turbidites and then shallow marine deposits is consistent with progressive shallowing of the basin, consistent with foraminiferaderived paleobathymetry.

The age and paleobathymetry constraints presented here for the Sabau section do not agree with previous results of the timing of uplift in the Sabau section or other sections of the Central Basin (e.g. De Smet et al., 1990). Our measured thickness of the Sabau section is somewhat less than the previous estimate of $\sim 550 \mathrm{~m}$ (De Smet et al., 1990), but we find the shoaling of paleobathymetry from lower to middle bathyal depths at the same stratigraphic level as documented previously, that is, between the upper chalks and the upper mass-flow dominated coarse clastics (De Smet et al., 1990). However, previous foraminiferal age constraints suggested that basal Batu Putih deposition began at $\sim 3.0 \mathrm{Ma}$, that coarse mass-flow deposition and uplift from lower bathyal to middle bathyal depths occurred between 2.2 and $2.0 \mathrm{Ma}$, and that the top of the upper clays and turbidites unit was deposited at only $0.2 \mathrm{Ma}$ (De Smet et al., 1990). De Smet et al. (1990) recorded Sphaeroidinella at the base of the Sabau section, yet we found it appearing only beginning at $10.5 \mathrm{~m}$, contributing to our age revision for the base of the section. Our identification of Globigerinoides obliquus at the top of the section requires an age older than $1.30 \mathrm{Ma}$, necessitating our age revision for the top of the section. As summarized in Fig. 9, our revised age constraints on the Sabau section eliminate the apparent diachroneity in onset of sedimentation and timing of uplift in the Viqueque Sequence across Timor as was suggested by De Smet et al. (1990). We additionally eliminate the need for a $7.5 \mathrm{~mm} / \mathrm{yr}$ pulse of uplift at the Sabau section from middle bathyal depths to modern elevations after $0.2 \mathrm{Ma}$ as required by the age of the top of the section from De Smet et al. (1990). Instead, our results suggest that in the Sabau section: A) basal Viqueque Sequence deposition was at 5.57-5.53 Ma, B) uplift from lower to middle bathyal depths occurred between 3.35 and $2.58 \mathrm{Ma}, \mathrm{C}$ ) uplift from middle to upper bathyal depths occurred between 2.58 and $1.30 \mathrm{Ma}$, and D) the average uplift rate since $1.30 \mathrm{Ma}$ was $0.8 \mathrm{~mm} / \mathrm{yr}$, with no need for a rapid pulse of uplift since $0.2 \mathrm{Ma}$.

\section{Thermochronology}

\subsection{Thermochronology methods}

\subsubsection{Apatite and zircon (U-Th)/He}

Ten sandstone samples were collected for (U-Th)/He thermochronology from Gondwana Sequence units of the Kekneno Window. Samples were approximately $8 \mathrm{~kg}$ each and had $\geq 200 \mu \mathrm{m}$ grain size in hand sample. Standard magnetic and heavy liquid techniques were used to separate apatite and zircon grains. Sample processing was conducted at the University of Arizona Radiogenic Helium Dating Laboratory. Each of the ten samples was processed for apatite (U-Th)/He (AHe) and four of those ten samples were also processed for zircon (U-Th)/He (ZHe). Three to five apatite grains (depending on availability) were picked from each of the ten samples and three zircon grains were picked from each of the four ZHe samples. Each grain had a minimum width of $60 \mu \mathrm{m}$, and apatites were inclusion-free except where noted in Table S1. Each grain was degassed individually by laser heating to measure He content, after which U-Th-Sm content was determined using Inductively Coupled Plasma Mass Spectrometry. For more information on (U-Th)/He thermochronology methods see Reiners et al. (2004).

\subsubsection{Apatite fission track}

Eight of the samples used for (U-Th)/He analyses were also analyzed for apatite fission track (AFT) thermochronology. Analysis of fission tracks employed the external detector method with zeta-age calibration (Hurford and Green, 1983). Irradiation of samples took place at the Oregon State University Radiation Center with a nominal neutron fluence of $1 \mathrm{e} 16 \mathrm{n} \mathrm{cm}^{-2}$. We counted zero or very few spontaneous tracks in a significant number of grains, leading to high analytical uncertainty for young grains and samples. One sample yielded a slightly 

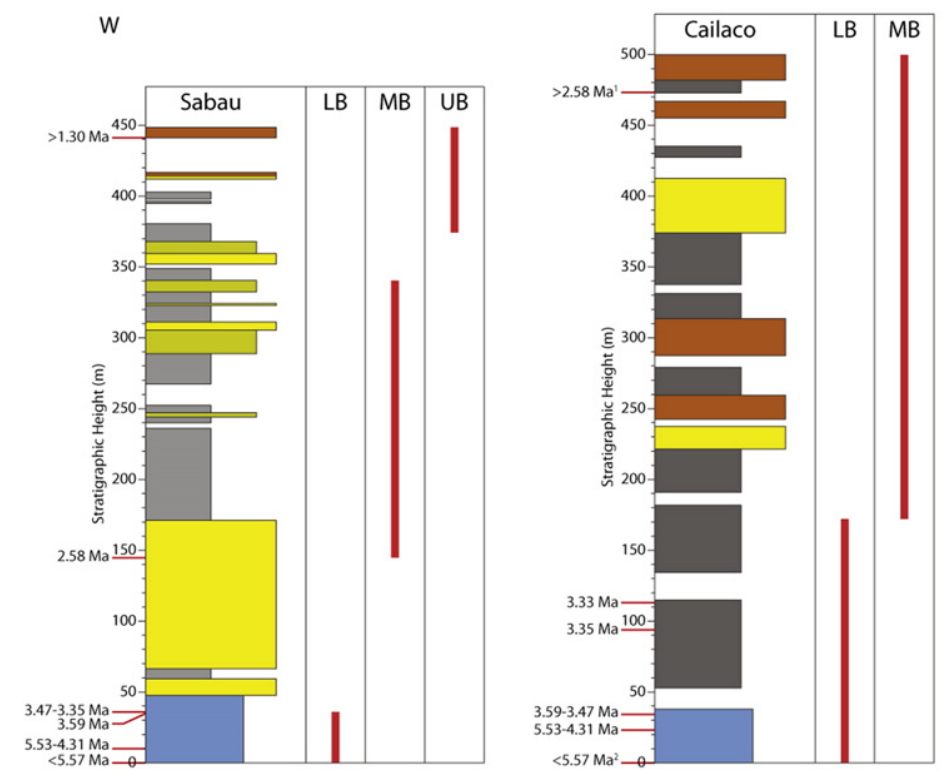

$\mathrm{E}$
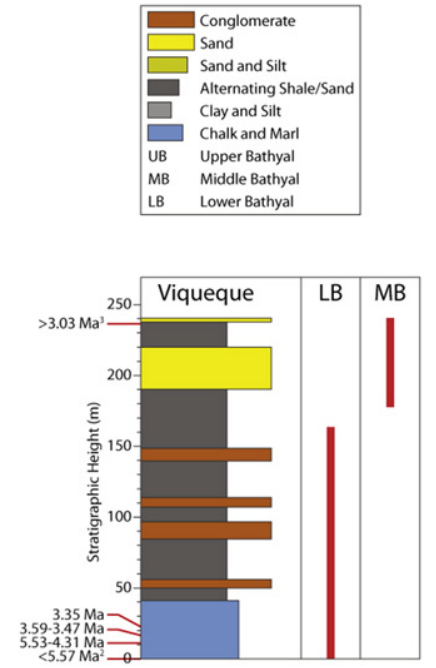

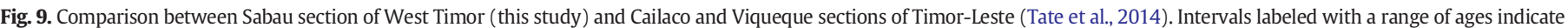

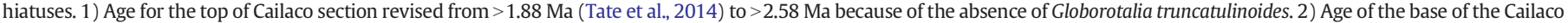

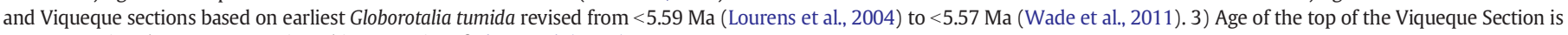
$>3.03$ Ma using the magnetostratigraphic constraint of Aben et al. (2014).

younger age when comparatively analyzed by the laser ablation method (which allowed for inclusion of more grains that have few induced and spontaneous tracks). This raises the possibility that the external detector method AFT ages reported here are biased slightly toward being too old. However, we consider these uncertainties unavoidable for such young samples, and therefore emphasize the reported analytical uncertainties.

\subsection{Thermochronology results}

Thermochronology results are shown in Fig. 10a and are listed in Table S1. In each of samples TB12-13, TB12-46 and TB12-131 one anomalous grain age was removed from analysis when calculating $\mathrm{AHe}$ sample weighted means. Two anomalously high AHe ages were removed from the sample weighted mean of TB12-27, as old ages relative to the timing of deformation on Timor and the structural position of this sample suggests the scatter in single-grain ages of this sample may be due to time spent in the partial retention zone.

AHe ages correlate well with mapped structures in the Kekneno window. The youngest samples, with ages of $0.33 \pm 0.10 \mathrm{Ma}, 0.37 \pm$ $0.19 \mathrm{Ma}$, and $0.49 \pm 0.27 \mathrm{Ma}$, are located along the antiform axis where the deepest structural levels in the window are exposed at the surface. Ages become progressively older south of the antiform axis, with ages of $0.74 \pm 0.24 \mathrm{Ma}$ and $0.95 \pm 0.25 \mathrm{Ma}$ on Mt. Kekneno, 1.12 \pm 0.34 and $1.39 \pm 0.14$ near Lilana, and $1.49 \pm 0.57$ and $1.59 \pm 0.50$ just below the structural contact with the overlying Bobonaro mélange. The oldest AHe age of $2.76 \pm 0.25 \mathrm{Ma}$ is found near Nenas at the eastern plunging margin of the duplex just below the structural contact with the Bobonaro mélange, and as noted above may be influenced by time spent in the partial retention zone.

ZHe analyses find no grains completely reset during orogenesis on Timor, as the youngest single-grain age of $14.07 \mathrm{Ma}$ is older than estimates of initial collision of the Banda forearc with the Australian margin (Berry and McDougall, 1986; Keep and Haig, 2010; Tate et al., 2014; Tate et al., 2015). However, ZHe ages suggest varying degrees of partial resetting between samples. The youngest $\mathrm{ZHe}$ ages are found for the three samples with youngest AHe ages of 0.33-0.49 located along the axis of the antiform. ZHe ages of 14 to $124 \mathrm{Ma}$ are much younger than the Permian to Triassic age of deposition, suggesting partial resetting. ZHe ages are older and only suggest very slight resetting for the sample on Mt. Kekneno with an older AHe age of $0.74 \pm 0.24$.

AFT analyses find four samples with reset fission track age populations (Chi-squared probability $\geq 5 \%$ ) and four samples with partially reset ages. No samples are interpreted as having completely unreset AFT ages, as each sample has central and pooled ages less than the onset of exhumation documented in Timor-Leste at $7.13 \pm 0.25 \mathrm{Ma}$ (Tate et al., 2014). The degree of AFT resetting correlates well with AHe age, as the four reset AFT ages are found from those samples with the youngest AHe ages. Youngest AFT central ages of $2.19 \mathrm{Ma}$ (95\% confidence interval 1.54-3.13 Ma) and 2.4 Ma (95\% confidence interval 1.62-3.54 Ma) are found along the central antiform axis. Older AFT ages of $3.31 \mathrm{Ma}$ (95\% confidence interval 2.54-4.31 Ma) and $3.53 \mathrm{Ma}$ (95\% confidence interval 2.72-4.57 Ma) are found on a ridge south of the peak of Mt. Kekneno and in the town of Lilana, respectively. Partially reset AFT ages are found along the margins of the Kekneno window close to the contact between Gondwana Sequence strata and the Bobonaro mélange, as well as west of the town of Lilana. We note that these AFT ages and resetting patterns are consistent with results from Harris et al. (2000). Those authors found AFT samples to possess various degrees of partial resetting north of our mapped antiform axis, reporting calculated central ages ranging from $4 \pm 1.5$ to $19.2 \pm 9.7$. We also note that AFT ages of 3.31 and $3.53 \mathrm{Ma}$ are coincident with or shortly predate our documented uplift and coarse clastic deposition in the Sabau section and provide further evidence of an emergent and eroding West Timor earlier than documented by De Smet et al. (1990).

\subsection{Thermal modeling}

Thermal modeling of exhumation rate and exhumation magnitude was performed on AHe and AFT results using the procedures of Willett and Brandon (2013). This one-dimensional model incorporates the effects of a transient geothermal gradient during exhumation as well as the effect of cooling rate on closure temperature. Kinematic parameters for this modeling (listed in Table S1) are taken from Farley (2002) for AHe and from Ketcham et al. (1999) for AFT. Mean local elevations, within radii of $4 \mathrm{~km}$ and $9 \mathrm{~km}$ for AHe and AFT respectively, are used for each sample to account for the effect of topography on isotherms with depth (Willett and Brandon, 2013). Surface temperature 

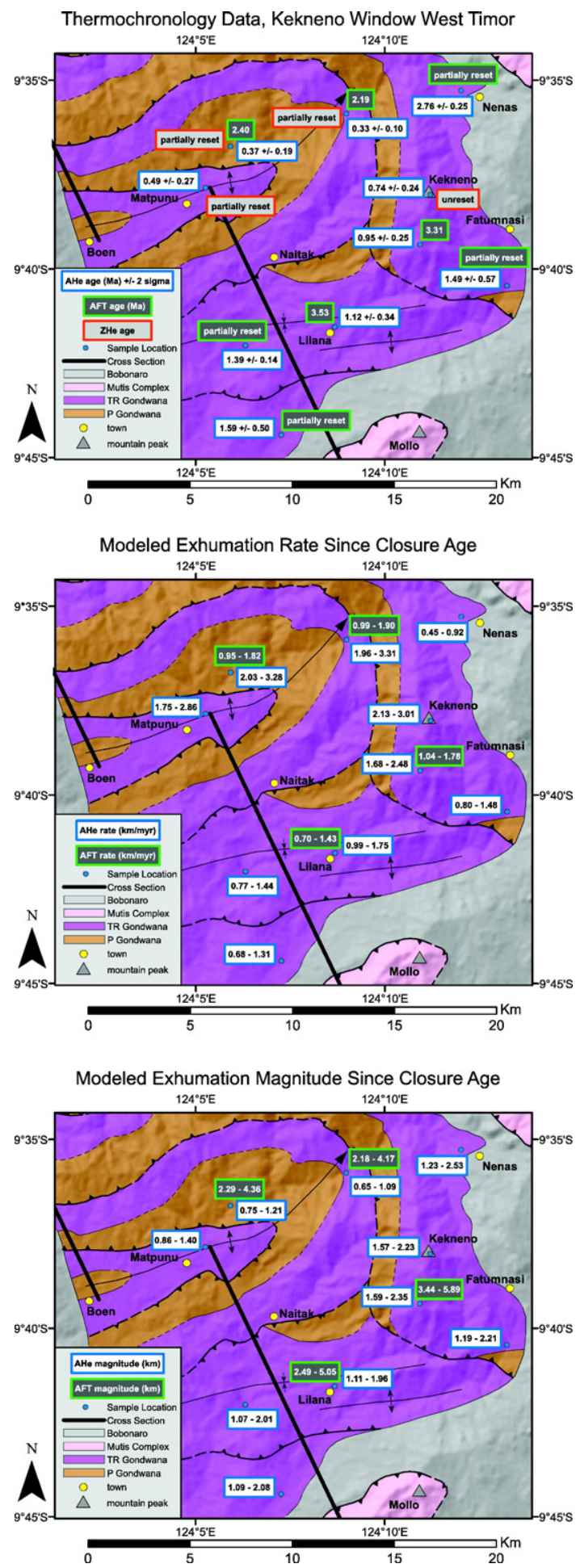

Fig. 10. Top: Apatite (U-Th)/He (AHe), apatite fission track (AFT) and zircon (U-Th)/He (ZHe) ages in the Kekneno window. Middle: Exhumation rate since apatite (U-Th)/He (AHe) or apatite fission track (AFT) closure age from thermal modeling. Bottom: Exhumation magnitude since apatite (U-Th)/He (AHe) or apatite fission track (AFT) closure age from thermal modeling.

for each sample follows the modern-day mean annual temperature of $27^{\circ} \mathrm{C}$ at sea level decreasing by $6{ }^{\circ} \mathrm{C}$ every km of elevation. Model results discussed below and presented in Fig. 10b and c assume a time of initiation of exhumation $\left(\mathrm{t}_{1}\right)$ at $4.5 \mathrm{Ma}$, which palynology (Nguyen et al., 2013) and thermochronology (Tate et al., 2014) suggest is the timing of island emergence in Timor-Leste. Model results are also included in Table $\mathrm{S} 1$ for $\mathrm{t}_{1}=7.1 \mathrm{Ma}$, the earliest exhumation in Timor-Leste and consistent with AHe thermal models in Tate et al. (2014). Varying $t_{1}$ from 4.5 to 7.1 only varies modeled exhumation rates and exhumation magnitudes by about $10 \%$. While $7.1 \mathrm{Ma}$ provides an upper bound on the age of earliest exhumation, we prefer $t_{1}=4.5$ Ma because the tectonostratigraphic unit of Timor-Leste that suggests exhumation as old as 7.1 Ma (Tate et al., 2014) is not found in West Timor. We do not favor modeling earliest exhumation coeval with uplift of the Sabau section between 3.35 and 2.58 Ma because A) an AFT age of 3.53 Ma indicates exhumation pre-dating uplift at the Sabau section and B) earliest pollen input from island emergence is detected prior to synorogenic basin uplift in the Viqueque Sequence of Timor-Leste (Nguyen et al., 2013). The range of thermal modeling results discussed below and the results found in Table S1 use pre-exhumation geothermal gradients of 15,25 and $32{ }^{\circ} \mathrm{C} / \mathrm{km} .15{ }^{\circ} \mathrm{C} / \mathrm{km}$ is the lowest geothermal gradient found in wells in Timor and Savu in areas that have experienced thrust stacking but little exhumation (Kenyon and Beddoes, 1977; Harris et al., 2000). $32{ }^{\circ} \mathrm{C} / \mathrm{km}$ is the present-day geotherm of the Australian passive margin (O'Brien et al., 1996), our best estimate for the pre-deformation geotherm of strata now incorporated in the Timor orogen. We would expect the pre-exhumation geotherm to have been $<32^{\circ} \mathrm{C} / \mathrm{km}$, as thrust stacking of cold upper Australian strata likely depressed the pre-deformation geotherm before emergence and exhumation (Tate et al., 2014).

Modeled exhumation rates since AHe closure follow a pattern similar to AHe ages (Fig. 10b). Since the time of AHe closure, the fastest exhumation rates of $1.75-3.31 \mathrm{~km} / \mathrm{Myr}$ are found along the antiform axis at samples with AHe ages of 0.33-0.49 Ma. Similar exhumation rates of $1.68-3.01 \mathrm{~km} /$ Myr for slightly older AHe ages of $0.74-0.95 \mathrm{Ma}$ found on Mt. Kekneno. Similar exhumation rates for these different closure ages are reasonable because the older ages are found on mountain peaks higher than their $4 \mathrm{~km}$ mean local elevations while the younger ages are found at valley floors. Modeled exhumation rates since AHe closure are slower (0.45-1.75 km/Myr) for other AHe samples to the south and to the east where the duplex begins to plunge below overlying Bobonaro mélange. Modeled exhumation rates since AFT resetting are also fastest along the central antiform axis and on Mt. Kekneno, ranging from $0.95-1.82 \mathrm{~km} / \mathrm{Myr}$. Slower exhumation rates since AFT closure of $0.70-1.43 \mathrm{~km} / \mathrm{Myr}$ are found in the sample west of Lilana. As exhumation rates since AHe closure are modeled to have been faster than exhumation rates since AFT closure for those samples that are double-dated, it appears that exhumation rates at those sample locations have increased since AHe closure at about 1.12 to $0.33 \mathrm{Ma}$.

Modeled exhumation magnitudes since AHe and AFT closure (Fig. 10c) are anticorrelated with exhumation rate, and range from 0.65 to $2.53 \mathrm{~km}$ for AHe and 2.18 to $5.89 \mathrm{~km}$ for AFT. Because each one-dimensional model is independent, the modern geotherm modeled from AHe data in this $\sim 10 \mathrm{~km}$-wide area is predicted to vary between locations by $>30^{\circ} \mathrm{C} / \mathrm{km}$, which is perhaps unreasonable. We note also that these predicted exhumation magnitudes only apply since the time of closure and that total exhumation may have been greater than this in many locations. We therefore argue that total exhumation was greatest along the antiform axis, because a) these units occupy a position structurally below the greatest modeled exhumation magnitudes of 3.44$5.89 \mathrm{~km}$ on Mt. Kekneno and b) these units produce partially reset ZHe ages.

\section{Balanced cross section}

\subsection{Cross section methods}

A balanced cross section through the map area in West Timor is presented in Fig. 11. We employ a $2^{\circ}$ décollement dip that allows us to match the results of both seismic reflection studies (Richardson and Blundell, 1996) and seismic refraction studies (Shulgin et al., 2009) that show $10-12 \mathrm{~km}$ of structural thickening below Timor and the nearby island of Savu. Seismic reflection data from Snyder et al. (1996) inform the location and dip of the southeastern-most thrust in the 

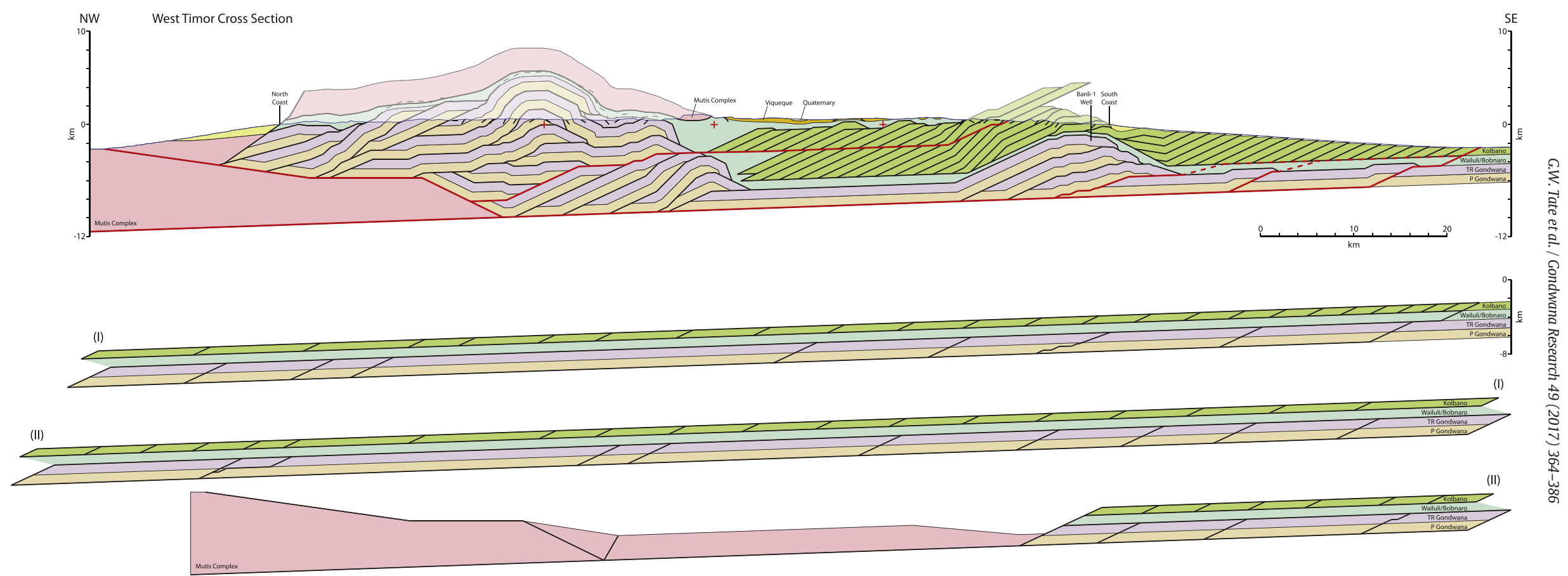

Fig. 11. Balanced cross section through area of structural mapping in West Timor. Deformed section above, restored section in three pieces below. Colors used as in Fig. 2. Paths of active slip highlighted in red. 


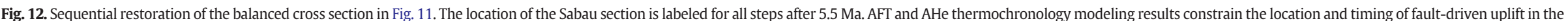
Kekneno window at the labeled points and time steps. Lower left inset: illustration of shortening and continental subduction calculations. 
Gondwana Sequence. Seismic reflection data (Snyder et al., 1996) and well observations (Harris et al., 2009) suggest backthrusting of the northern Timor margin over the Banda forearc.

Unit thicknesses match those that we map at the surface of Timor: $1 \mathrm{~km}$ each for the Permian and Triassic stratigraphy and $800 \mathrm{~m}$ for the Kolbano Sequence. It is possible that there is undocumented thickness variation of Gondwana Sequence strata deformed below Timor, as thickness variations and normal faulting are found on the present Australian shelf (Tripathi et al., 2012; Baillie and Milne, 2014; Saqab et al., 2017). We do not incorporate such thickness variations in this cross section, however, as a) thickness variation is not seen in the units mapped on land, so any schematic thickness variation in the subsurface would be highly conjectural, and b) similar unit thicknesses in Timor-Leste (Tate et al., 2015) and in some places on the Australian shelf (Karig et al., 1987; Snyder et al., 1996) suggest generally consistent thicknesses at a broad scale despite local thickness variations. Wailuli Formation thickness is not preserved in the cross section as this unit is incorporated as the matrix of the Bobonaro mélange.

The Banli-1 well location is projected from $9 \mathrm{~km}$ northeast of the section, and subsurface geometries match the Banli- 1 well constraints of a major thrust within the Kolbano thrust stack, depths to unit contacts, and gradually shallowing southeast dips in the Triassic (Sani et al., 1995). Topography and bathymetry at the surface (Smith and Sandwell, 1997) as well as mapped units, structures, and dips constrain the upper surface of the cross section. Kink methods following Suppe (1983) are used to constrain fault and fold geometries. Thermochronologic data and thermal modeling results presented above are used to identify locations of recent and active structures driving uplift and exhumation at the surface. A break in the cross section trace shown in Fig. 5a crosses what Charlton et al. (1991) have mapped as the Mena-Mena strike-slip fault, potentially affecting our shortening estimate on the order of $10 \mathrm{~km}$.

\subsection{Cross section interpretation}

Thin-skinned thrusting of Permian and Triassic Gondwana Sequence strata is interpreted to fill the majority of the cross section in the subsurface (Fig. 11). This interpretation follows directly from the map pattern at the surface (Fig. 5b), which documents thrust repetition of Permian and Triassic Gondwana Sequence strata. Some authors have instead previously interpreted significant basement-involved inversion structures below Timor (e.g. Reed et al., 1996; Charlton, 2002a; Charlton, 2002b). We would note, however, that Charlton (2002a, 2002b) and Reed et al. (1996) also interpreted the Lolotoi Complex (correlative to the Mutis Complex in Timor-Leste) as Australian pre-Permian basement exposed at the surface, an interpretation which if true would indeed necessitate basement-involved deformation. Zircon U-Pb ages from the Mutis and Lolotoi Complexes contain young populations from 82 to 34 Ma (Harris, 2006; Standley and Harris, 2009), showing that these units are too young to be pre-Permian basement. Additionally, interpreting the Mutis Complex in our map area (Fig. 5) as Australian basement would be inconsistent with the anticline-syncline map pattern of the Kekneno antiform and circular Mutis Complex klippen. Further, our thermochronology data and modeling (Fig. 10) suggests that the most exhumation has occurred at the center of Kekneno window, whereas one might expect the most exhumation on the eastern and southern margins of the window if the Mutis Complex were Australian basement. With the above observations we conclude that the Mutis Complex is not Australian basement, and therefore basement-involved deformation of the Australian margin at Timor is not required by the units exposed at the surface.

Beyond this, there is a possibility of basement-involved inversion structures that are restricted to the subsurface below Timor, especially considering the normal faulting that was likely present in the pre-collisional margin as described in Section 3.1. Such basement-involved structures, however, would be expected to produce broad signals of uplift and exhumation (e.g. Coughlin et al., 1998; Sobel et al., 2006), contrary to the scale of spatial variation in thermochronology ages we observe. Additionally, two centers of active uplift driven by basementinvolved inversion below both the hinterland Kekneno window and the foreland Kolbano range would be kinematically infeasible, as convergent slip from the north could not be fed along a detachment to two different deep basement-involved structures at once. Lastly, inversion structures are typically characterized by sedimentary units that dramatically thicken as they approach inverted normal faults (e.g. Perez et al., 2016), and we do not observe such stratigraphic thickening in our map area. We therefore interpret thin-skinned deformation in the subsurface, as we consider it the most kinematically feasible and the most consistent with the surface geology. Seismic data offshore Timor (Tripathi et al., 2012; Baillie and Milne, 2014; Saqab et al., 2017) clearly demonstrate the plausibility of deforming strata that are cut by normal faults into thin-skinned thrust stacks, as the youngest Australian margin strata are observed to contain normal faults south of the Timor Trough and form a thin-skinned thrust stack north of the Timor Trough. Also, thin-skinned deformation similar to what we have interpreted in Timor is evident in shortened continental margin strata of Taiwan (Suppe, 1981), another prominent setting of active arc-continent accretion.

The cross section geometry (Fig. 11) in the hinterland of the orogen is dominated by an antiformal stack in the Kekneno window. This antiformal stack geometry matches the map pattern in the Kekneno window (Fig. 5b): a major anticline at Boen and Matpunu with beds and thrust faults dipping northwest on the northwest side of the anticline and dipping southeast on the southeast side. We propose fast exhumation at the core of this antiformal stack (as indicated by thermochronology) is driven by active thrusting up a ramp within the duplex below the Kekneno antiform. Slip up this ramp is fed from below by backthrusting over the Banda forearc, which also feeds slip to active thrusting offshore north of Timor. At the north coast, an inactive normal fault in the overthrust Banda klippe separates the overthrust Banda lid from Banda units offshore, similar to previous interpretations in Timor-Leste (Tate et al., 2015). Slip below the Kekneno window antiform is fed along a shallow décollement to Kolbano Sequence units in the foreland. Slip along these shallow Kolbano Sequence faults drove folding below Viqueque Sequence units in the Central Basin, active uplift of the hinterland Kolbano range, and the surface exposure of deeper Kolbano Sequence stratigraphy in hinterland Kolbano Sequence thrust sheets than in foreland thrust sheets. Active uplift of the Kolbano range, suggested by the strikingly steep topography of this coastal range, is also driven at depth by duplexing of a Gondwana Sequence culmination.

The cross section (Fig. 11) suggests $7.6 \mathrm{~km}$ of exhumation at the center of the Kekneno antiform, where we find the youngest AHe and AFT ages and where ZHe ages are partially reset. This structurally predicted exhumation magnitude is also permissible from our AFT thermal modeling because exhumation magnitudes of 3.4-5.9 km/Myr are modeled since AFT closure for the sample on top of Mt. Kekneno, which map patterns suggest is in a structural position $2-3 \mathrm{~km}$ above the core of the antiform. This exhumation magnitude of $7.6 \mathrm{~km}$ is similar to the $7.8 \mathrm{~km}$ modeled for the oldest ZHe age of $4.4 \pm 0.7 \mathrm{Ma}$ found in Timor-Leste, using the coldest pre-exhumation geotherm of $15^{\circ} \mathrm{C} / \mathrm{km}$ (Tate et al., 2014). Exhumation magnitudes suggested by structural observations, therefore, are in closest agreement with thermal models using a geothermal gradient severely depressed through thrust stacking of cold upper Australian strata prior to exhumation.

\subsection{Shortening and continental subduction}

Australian-affinity units restore to an undeformed Australian margin extending $350 \mathrm{~km}$ north of the Timor Trough. Banda-affinity units in this cross section restore to an undeformed length of $90 \mathrm{~km}$. The deformed length of this cross section from the Timor Trough to the 


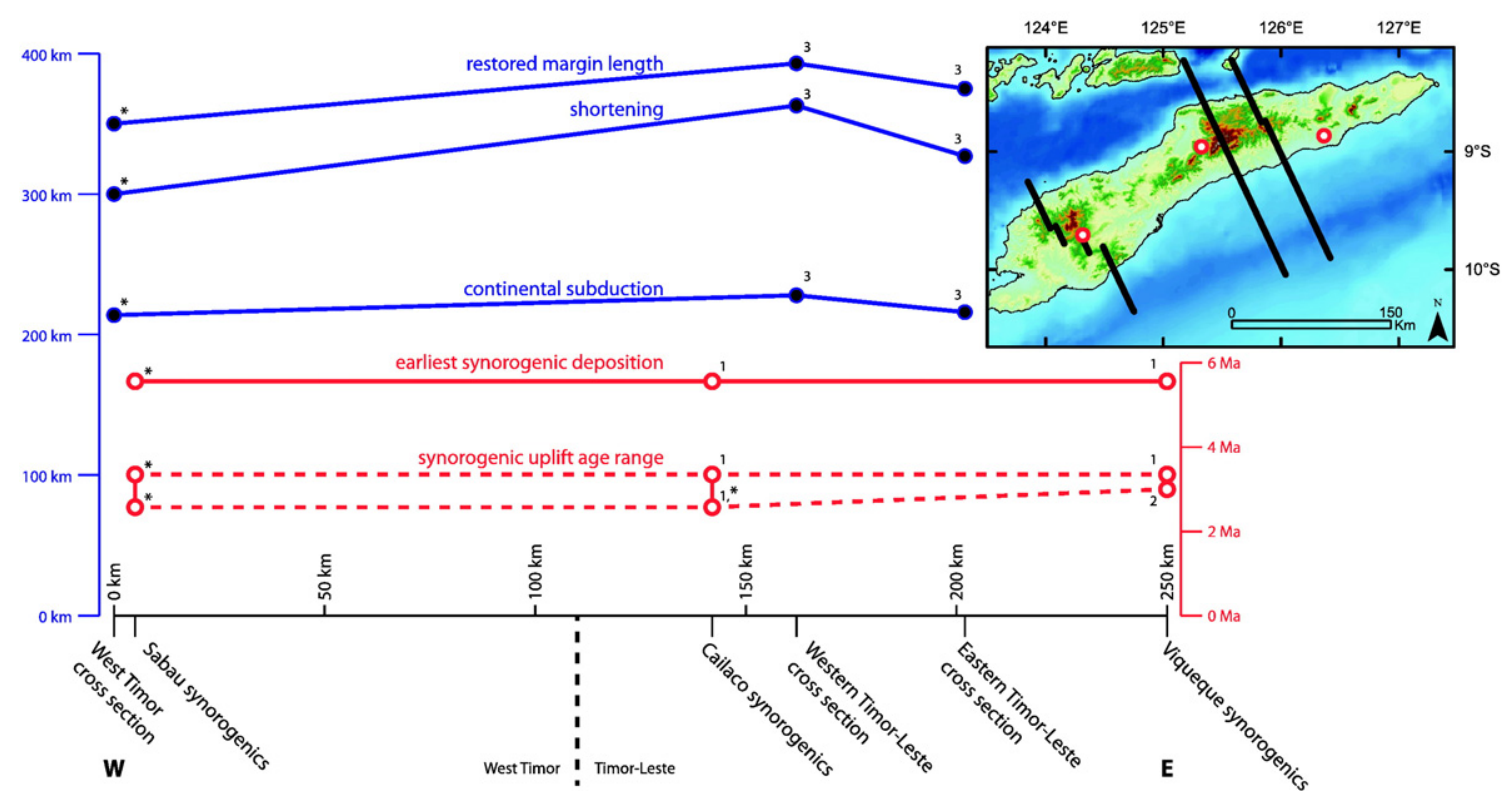

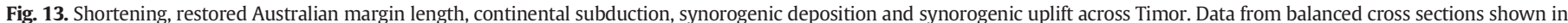

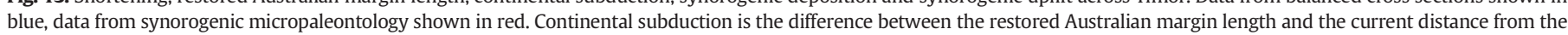

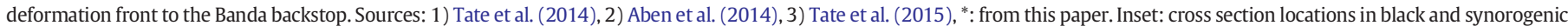
sections in red with SRTM topography and Smith and Sandwell (1997) bathymetry.

northern backthrust is $140 \mathrm{~km}$. These lengths suggest a minimum shortening amount of $300 \mathrm{~km}$, or $68 \%$ shortening (Fig. 12).

We also use this cross section to constrain the length of continental basement and lower crust subducted below the Banda forearc during the arc-continent collision that has built the Timor orogen. We calculate continental subduction by subtracting the distance between the deformation front and the undeformed backstop from the original length of the downgoing continental plate. Subtracting the current distance from the Timor Trough to the undeformed forearc of $140 \mathrm{~km}$ from the undeformed Australian margin length of $350 \mathrm{~km}$ shows that at least $210 \mathrm{~km}$ of Australian basement, lower crust and mantle lithosphere must have subducted below the Banda forearc (Fig. 12).

\subsection{Sequence of deformation}

A sequential restoration of this balanced cross section is shown in Fig. $12.10 \mathrm{~km}$ of shortening is restored between the present and $0.5 \mathrm{Ma}$, matching the present-day convergence rate between Timor and Australia of $20 \mathrm{~mm} / \mathrm{yr}$ (Nugroho et al., 2009). At the Gondwana Sequence level this shortening is partitioned between restored shortening at the southeast end near the Timor Trough, in the duplex below the Kolbano range at the southern coast, below the antiformal stack of the Kekneno window, and on the backthrust at the northwestern end of the section. Restored shortening below the Kekneno window matches the $1 \mathrm{~km}$ of uplift that the antiform axis has experienced between $0.5 \mathrm{Ma}$ and the present, as documented by the AHe results. Restored shortening below the Kekneno window is linked to shortening along a shallow detachment within the Kolbano stack.

$24 \mathrm{~km}$ of shortening is restored between 0.5 and $1.5 \mathrm{Ma}$, partitioned between the duplex below the Kolbano range, the antiformal stack of the Kolbano window, and the backthrust at the NW end. Shortening below the Kekneno window matches $1.5 \mathrm{~km}$ of uplift from $1.5 \mathrm{Ma}$ to present in the southern Kekneno window near Lilana, as documented by AHe results. The Sabau section is located at shallow marine depths at about this time.

$27 \mathrm{~km}$ of shortening is restored between 1.5 and 2.5 Ma. At 2.5 Ma, we show the duplex below the Kolbano range completely restored. Shortening below the Kekneno window matches $3.3 \mathrm{~km}$ of exhumation at the antiform axis from $2.5 \mathrm{Ma}$ to present, as documented by AFT results. Further shortening is restored in the duplex below the Sabau section and along the northwestern backthrust. The Sabau section is located at middle bathyal depths and at $2.5 \mathrm{Ma}$ is at the end of the phase of proximal coarse clastic deposition likely sourced from the uplifting Kekneno window.

$29 \mathrm{~km}$ of shortening is restored between 2.5 and 3.5 Ma. Shortening below the Kekneno window matches $3.8 \mathrm{~km}$ of exhumation in the southern Kekneno window near Lilana, as shown by AFT results. Duplexing below Sabau as restored at this step is linked to uplift of the Sabau section from lower bathyal to middle bathyal depths between 3.35 and $2.58 \mathrm{Ma}$. A significantly lower Kekneno duplex at 3.5 Ma than at $2.5 \mathrm{Ma}$ as drawn here is consistent with the stratigraphic transition in the Sabau section from low-energy chalks to high-energy coarse clastic deposits between 3.35 and $2.58 \mathrm{Ma}$.

$49 \mathrm{~km}$ of shortening is restored between 3.5 and $5.5 \mathrm{Ma}$. All duplexing of the Gondwana Sequence below the Sabau section is restored, and additional duplexing is restored below the southern Kekneno window. All backthrusting of Gondwana Sequence units to the northwest over the Banda forearc is restored here by $5.5 \mathrm{Ma}$. The timing of fault motion and resulting uplift below the central and southern Kekneno window is well-constrained in this sequential restoration by thermochronology data, but the timing of backthrusting is poorly constrained due to a lack of thermochronology data between the central Kekneno window and the north coast. In Timor-Leste, backthrusting over the Banda forearc has been linked to a widespread phase of emergence at $4.5 \mathrm{Ma}$ (Tate et al., 2015). By 5.5 Ma, the Mutis Complex has overthrust the Gondwana Sequence, a duplex of Gondwana Sequence units has developed below the Mutis overthrust sheet, and the Kolbano thrust stack has developed to the southeast. Additionally, the Bobonaro mélange has developed between the Gondwana Sequence duplex and the overriding units, and has also been emplaced above the hinterland part of the Kolbano thrust stack. Viqueque Sequence deposition has begun at the Sabau section at lower bathyal depths in the wedge-top low between the highs of the Gondwana Sequence duplex and the center of the Kolbano thrust stack. Viqueque Sequence deposition at the Sabau section is of the low-energy chalks unit, suggesting no proximal emergent sediment source. 
$161 \mathrm{~km}$ of shortening is restored between $5.5 \mathrm{Ma}$ and the beginning of deformation. The rate of shortening before $5.5 \mathrm{Ma}$ was at most the plate convergence rate between Australia and Asia of $\sim 70 \mathrm{~km} / \mathrm{m}$.y. (Nugroho et al., 2009; Spakman and Hall, 2010; Seton et al., 2012; Koulali et al., 2016). This suggests that collision and shortening began in West Timor by roughly $7.8 \mathrm{Ma}$.

\section{Discussion}

\subsection{Comparison of West Timor and Timor-Leste}

\subsubsection{Map patterns}

Map pattern observations suggest several key differences between the structural developments of eastern and western Timor. The Gondwana Sequence duplex in Timor-Leste has been mapped as a hinterland-dipping duplex (Tate et al., 2015), whereas mapping of the Kekneno window presented here suggest that a significant portion of the Gondwana Sequence duplex in West Timor has developed as an antiformal stack. This would imply that the ratio of fault slip to fault spacing within the duplex is larger in West Timor, likely controlled by differences in the internal strength of horses or frictional resistance along the slip horizon at the base of the Permian. Significant differences exist between the stratigraphies of eastern and western Timor that may control such differences in horse strength, as for instance the lower abundance of Aitutu Formation limestones in West Timor. This could lead to slightly weaker internal strength and therefore closer duplex fault spacing and shorter horses. Additionally, West Timor is broader than Timor-Leste and exposes more of the foreland of the thrust belt at the surface, whereas Timor-Leste exposes more of the hinterland. For example, mapped exposures of the Viqueque Sequence in the Central Basin (Rosidi et al., 1979) have a much wider extent than those found in Timor-Leste (Audley-Charles, 1968; Tate et al., 2015). Our mapping confirms that these Central Basin deposits are deformed only by very broad, low-amplitude folding. Also, mapped Kolbano Sequence exposures in the high-elevation Kolbano range differ significantly from Timor-Leste, where Kolbano Sequence limestones are poorly exposed in low-elevation regions near the south coast (Audley-Charles, 1968; Tate et al., 2015). Because these Kolbano Sequence units along the southern coast have much steeper topography in West Timor, it appears that modern subsurface duplexing and surface faulting drive active Kolbano Sequence uplift in West Timor but not in Timor-Leste.

\subsubsection{Synorogenic deposition and uplift}

Contrary to previous studies, our revised age and paleobathymetry constraints of the Sabau section show no detectable difference in earliest deposition age and uplift timing from Viqueque Sequence deposits in Timor-Leste (Figs. 9 and 13). Basal Batu Putih deposits in TimorLeste are also dated between 5.57 and $5.53 \mathrm{Ma}$ (Tate et al., 2014). The hiatus from 5.53 to $4.31 \mathrm{Ma}$ is present in both West Timor and TimorLeste (Tate et al., 2014), perhaps reflecting a regional phase of non-deposition or erosion due to deep-marine currents. Similarly, short hiatuses of 3.47-3.35 Ma in West Timor and 3.59-3.47 Ma in Timor Leste (Tate et al., 2014) may represent the same hiatus, as the age difference may be an artifact of low quantities of tosaensis specimens. Shoaling from lower to middle bathyal depths in the Viqueque Sequence is documented between $3.35 \mathrm{Ma}$ and 3.0 Ma in the Viqueque section of TimorLeste (Aben et al., 2014; Tate et al., 2014), between 3.33 Ma and 2.58 Ma in the Cailaco section of Timor-Leste (Tate et al., 2014), and between 3.35 Ma and 2.58 Ma in the Sabau section of West Timor. (Note that the absence of Globorotalia truncatulinoides in the Cailaco section despite its prevalence in the Sabau section suggests that the top of the Cailaco section is $>2.58 \mathrm{Ma}$, not $>1.88 \mathrm{Ma}$ as concluded in Tate et al., 2014.) The Viqueque section and Cailaco section in Timor-Leste, however, do not contain the mass-flow dominated coarse clastics unit between the chalks unit and clay dominated unit that is found in the Sabau section from 48 to $171 \mathrm{~m}$. This suggests that either the Sabau section was much closer to a clastic sediment source shortly after 3.35 Ma than those sections in Timor-Leste or that the Sabau section preserves an evulsing depocenter of coarse clastics that was not similarly preserved in Timor-Leste. The average sedimentation rate for the whole section, however, is slower for the Sabau section than the Viqueque and Cailaco sections. Additionally, the top of the measured Sabau section is both younger and shallower than the measured Viqueque and Cailaco sections in Timor-Leste (Fig. 9).

These combined constraints suggest that significant deformation and orogenic wedge development must have occurred across the whole length of Timor prior to $5.5 \mathrm{Ma}$, as Viqueque Sequence deposits are deposited upon the Bobonaro tectonic mélange. Additionally, coarse clastic mass-flow deposition shortly after 3.35 Ma demonstrates proximal island emergence above sea level close to the central basin of West Timor at or before this time. It is permissible for an island to have been emergent in West Timor even earlier than $3.35 \mathrm{Ma}$ and concurrent with basal Viqueque Sequence chalk and marl deposition, as palynology within similar Batu Putih limestones in Timor-Leste suggests island emergence at $4.45 \mathrm{Ma}$, before deposition of clastic sequences in that preserved section (Nguyen et al., 2013). Lastly, uplift of Viqueque Sequence basins from lower to middle bathyal depths is synchronous to within 350-750 kyrs. This suggests that similar processes drove uplift across the island. We suggest that duplexing of Australian margin strata below synorogenic basins provides a means of differential uplift between basins and nearby Gondwana Sequence strata, similar to Timor-Leste where duplexing has been used to explain spatial variations in exhumation (Tate et al., 2014).

\subsubsection{Age and rate of exhumation}

Comparing thermochronology data between West Timor and Timor-Leste, AHe ages in West Timor ranging from 0.33 to $2.76 \mathrm{Ma}$, are significantly younger than AHe ages in Timor-Leste ranging from 1.4 to $5.5 \mathrm{Ma}$ (Tate et al., 2014). However, modeled exhumation rates of 2.0 to $3.3 \mathrm{~km} / \mathrm{Myr}$ for the youngest AHe ages in West Timor are equal to the fastest modeled exhumation rates in Timor-Leste from zircon (U-Th)/He data where apatites were not available for analysis (Tate et al., 2014). Both regions of rapid, young exhumation are interpreted to be regions of active subsurface deformation. This process, which facilitates active deformation in the hinterland of the orogen in both eastern and western Timor, despite less total exhumation occurring in West Timor, also promotes large along-strike gradients in exhumation magnitude and age. The Kekneno window displays large variation in exhumation rate correlating to position in the structural antiform suggesting a direct correlation between active deformation and exhumation. The spatial scale of exhumation provides insight into the depth and extent of the structures facilitating uplift. We argue that subsurface duplexing drives active growth of this antiform and the resulting exhumation gradient, similar to processes in Timor-Leste (Tate et al., 2014).

The data presented here support the interpretation of active shortening between Timor and Australia. Some have suggested that uplift beginning with shoaling observed in the Viqueque Sequence was driven by slab breakoff and isostatic rebound (Mccaffrey et al., 1985; Charlton, 1991; Sandiford, 2008; Ely and Sandiford, 2010; Keep and Haig, 2010). Wholesale island uplift due to slab breakoff, however, cannot explain the rapid and variable exhumation history from thermochronology ages found within the Kekneno window, which follows mapped patterns of thrust stacking. This laterally variable exhumation is highlighted further when considering the areas adjacent to the Kekneno window, as the Kekneno area was emergent and eroding during deposition at the Sabau section. The lateral variability in uplift magnitude and timing is explained better by subsurface duplexing (as illustrated sequentially in Fig. 12) than by isostatic uplift of the whole island. Similar arguments have also led to the conclusion that active shortening and subsurface duplexing best explain uplift patterns in Timor-Leste (Tate et al., 2014). Active convergence and shortening is also favored by the observations of modern GPS convergence between 
Timor and Australia of about $20 \mathrm{~mm} / \mathrm{yr}$ (Nugroho et al., 2009) or up to $32 \pm 2 \mathrm{~mm} / \mathrm{yr}$ (Koulali et al., 2016), short-wavelength uplift patterns of coral terraces (Merritts et al., 1998; Cox, 2009), and an unbroken tomographic image of the downgoing slab (Fichtner et al., 2010; Spakman and Hall, 2010).

\subsubsection{Magnitude of shortening}

Shortening and continental subduction as measured from balanced cross sections from this paper and from Tate et al. (2015) are summarized in Fig. 13. We find a minimum of $300 \mathrm{~km}$ of shortening in West Timor, whereas $143-180 \mathrm{~km}$ along strike to the east a minimum shortening magnitude of $362 \mathrm{~km}$ is found in western Timor-Leste, and $40 \mathrm{~km}$ further to the east a minimum of $326 \mathrm{~km}$ of shortening is found in another cross section (Tate et al., 2015). Shortening is less along this cross section in West Timor than along the two cross sections in Timor-Leste. However, the difference is not large enough to be consistent with East-West propagation of collision at $110 \mathrm{~km} / \mathrm{Myr}$ predicted by Harris (1991). Trough-perpendicular GPS convergence of $53 \mathrm{~mm} / \mathrm{yr}$ (Nugroho et al., 2009) would predict 69-87 km more shortening in western Timor-Leste and 88-106 km more shortening in eastern Timor-Leste than in West Timor. Moreover, the cross sections here and in Tate et al. (2015) do not display a consistent pattern of decreasing shortening from east to west. Lastly, we note that the difference in shortening estimates between the two closely spaced sections is greater than the difference in shortening estimates of the easternmost and westernmost sections. In light of this last point, it is possible that undocumented shortening or other uncertainties account for much of the difference between these minimum shortening estimates.

Variations in margin length may have had stronger control over collision timing and shortening magnitude than the oblique convergence. Restored lengths of the Australian margin in these cross sections from east to west are 374, 394 (Tate et al., 2015), and $350 \mathrm{~km}$ (this paper), and differences in these margin lengths are similar to differences in shortening magnitude. This alternative interpretation agrees with Keep and Haig (2010), who suggested that a plateau similar to the Exmouth Plateau off western Australia has subducted at Timor instead of a relatively straight Australian margin that subducted obliquely below the Banda forearc. Saqab et al. (2017) show that if a Timor Plateau similar in scale to the Exmouth Plateau is added to the Australian margin in plate models such as those of Hall (2012), initial collision at Timor would be predicted to occur at about $6 \mathrm{Ma}$.

Continental subduction suggested by the cross section in West Timor is consistent with continental subduction suggested in TimorLeste. A minimum of $210 \mathrm{~km}$ of continental subduction beyond the Banda forearc backstop is suggested in West Timor, whereas a minimum of 215-229 km of continental subduction is suggested in TimorLeste (Tate et al., 2015). Results in West Timor are therefore consistent with the conclusion of Tate et al. (2015) that a significant length of continental crust and mantle lithosphere of the Australian margin has been subducted below the oceanic Banda lithosphere. This is contrary to earlier hypotheses suggesting that continental subduction during arc-continent collision or ophiolite obduction is short-lived (McKenzie, 1969; Dewey and Bird, 1970). Such subduction of continental material during arc-continent accretion has likely had a significant impact on elemental recycling within the Earth (Hildebrand and Bowring, 1999).

\subsubsection{Island-wide similarities}

In summary, we conclude that the main first-order tectonic characteristics of Timor are similar across the island: A) the onset of collision must be older than 5.57-5.53 Ma, B) piggyback synorogenic basins experience uplift between 3.35 and $2.58 \mathrm{Ma}, \mathrm{C}$ ) maximum exhumation rates in the core of the mountain belt are 2.0 to $3.3 \mathrm{~km} / \mathrm{Myr}$, and D) the amounts of shortening ( 300 to $362 \mathrm{~km}$ ) and continental subduction ( 210 to $229 \mathrm{~km}$ ) are more similar than predicted by oblique convergence. Because the timing, rate and magnitude of deformation and uplift are similar along strike, variations in orogen morphology are best explained by variations in the distribution and style of shortening within the wedge.

\subsection{Along-strike variation of deformation mechanisms}

A comparison of West Timor and Timor-Leste in map and cross section view reveals key differences in the distribution of shortening within the orogen. Several mechanisms of hinterland shortening in TimorLeste are conspicuously absent in West Timor. Less backthrusting of the Timor orogen toward the Banda Arc has occurred in West Timor, as evidenced by the increasing distance between Timor and the Banda Arc from east to west. Also, a slate belt such as that found in TimorLeste has not been exhumed in West Timor. We interpret the absence of this region of greater exhumation is possibly due to a lack of duplexing of underthrust Banda forearc in West Timor, in contrast to that predicted in Timor-Leste (Tate et al., 2015). Instead of concentrating shortening in the hinterland, much more shortening has been accommodated in the foreland in West Timor, which is expressed as a much shorter distance and steeper slope between the south coast and the Timor trough in the western part of the island than in the east (Fig. 1). It appears therefore that along-strike variations in surface geology and N-S position of the island are more strongly controlled by the distribution of shortening in the wedge than by total shortening, which varies only slightly. Several mechanisms may contribute to this relative concentration of shortening in the foreland. First, the backstop of the Banda forearc may have a greater internal strength below West Timor, discouraging duplexing after backthrusting of the Gondwana duplex over the forearc. Second, an asperity along the basal décollement may cause the basal friction to be higher below the Kolbano range than other areas along strike, steepening the offshore surface slope as a critical wedge response (Davis et al., 1983) via the formation of a Gondwana Sequence culmination below the south coast. Third, the large Central Basin may have acted as a wedge-top basin (Fillon et al., 2013), with deposition of the Viqueque Sequence and thicker, younger synorogenics tending to prohibit deformation below that basin and encourage deformation instead toward the hinterland (in the Kekneno window) and toward the foreland (at the Kolbano range).

A few key differences, therefore, appear to control the majority of the along-strike variation of deformation observed at Timor. Several external controls on orogenic development, such as inherited margin geometry and timing of collision (that together have the strongest control on shortening amount), have had minimal effect on the alongstrike variations in surface geology even though these controls were previously thought to be some of the most important (Harris, 1991). Instead, the presence of a large synorogenic wedge-top basin, plus possible inherited differences in backstop strength and basal friction, has had strong influence on the distribution of strain within the wedge. Additionally, inherited stratigraphic variation from carbonate to clasticdominated systems has appeared to cause variations in internal strength of underplated units, influencing duplex geometry along strike.

\section{Conclusions}

Direct comparison of structural, thermochronologic, and paleontologic observations in West Timor to previous studies in Timor-Leste provide new information on the similarities and differences in deformation along strike. Contrary to several previous studies, shortening, exhumation and uplift are similar in West Timor and Timor-Leste. Instead, along-strike morphological differences of the Timor orogen appear to be affected most heavily by 1 ) variability in the strength and friction characteristics of the wedge inherited from pre-collisional depositional environments or forearc development and 2) surface influences on deformation such as wedge-top sedimentation.

Patterns of deformation across the orogen, therefore, appear to act on two very different wavelengths. As previously documented in Timor-Leste (Tate et al., 2014) and supplemented here in West Timor, 
drastic heterogeneities in uplift and exhumation exist at the 5-10 km wavelength. We argue that this is driven by the small-scale architecture of duplexing and thrust stacking, in both West Timor and Timor-Leste (Tate et al., 2014). The comparison provided here between the eastern and western portions of the orogen, however, suggest that the aggregate, broad-scale shortening history remains remarkably consistent over length scales of hundreds of kilometers.

Supplementary data to this article can be found online at http://dx. doi.org/10.1016/j.gr.2017.06.008.

\section{Acknowledgements}

Many thanks to Nova Roosmawati for assistance in the field. Thanks also to Isabella Raffi for assistance with calcareous nannofossils. Uttam Chowdhury provided great assistance for the thermochronologic analyses. Ray Donelick was very helpful during refinement of AFT track counting practices and in methodological comparison to laser ablation AFT dating. We appreciate the assistance of RISTEK (the Indonesian State Ministry of Research and Technology) during field work. Thank you to Tim Charlton, Robert Hall, Jon Pownall and two anonymous reviewers for their very useful comments while revising this manuscript. This project has been supported by NSF grant number 0948449. Herwin Tiranda received support from the Bandung Institute of Technology. D.J.J.v.H. acknowledges funding through ERC Starting Grant 306810 (SINK) and NWO VIDI grant 864.11.004.

\section{References}

Abbott, M.J., Chamalaun, F.H., 1981. Geochronology of some Banda arc volcanics. In: Barber, A.J., Wiryosujono, S. (Eds.), The Geology and Tectonics of Eastern Indonesia. Vol. 2. Geological Research and Development Centre Special Publication, Bandung, Indonesia, pp. 253-268.

Aben, F.M., Dekkers, M.J., Bakker, R., Van Hinsbergen, D.J.J., Zachariasse, J., Tate, G.W. McQuarrie, N., Harris, R., Duffy, B., 2014. Untangling inconsistent magnetic polarity records through an integrated rock magnetic analysis: a case study on Neogene sections in East Timor. Geochemistry, Geophysics, Geosystems 15 (6), 2531-2554.

Audley-Charles, M.G., 1968. The Geology of Portuguese Timor. viii. Geological Society of London, London $75 \mathrm{pp}$.

Audley-Charles, M.G., 2011. Tectonic post-collision processes in Timor. In: Hall, R. Cottam, M.A. (Eds.), The SE Asian Gateway: History and Tectonics of the AustraliaAsia Collision. Geological Society of London Special Publication 355, pp. 241-266.

Backman, J., Raffi, I., Rio, D., Fornaciari, E., Palike, H., 2012. Biozonation and biochronology of Miocene through Pleistocene calcareous nannofossils from low and middle latitudes. Newsletters on Stratigraphy 45 (3), 221-244.

Baillie, P., Milne, C., 2014. New insights into prospectivity and tectonic evolution of the Banda Arc: evidence from broadband seismic data. Proceedings, Indonesian Petroleum Association, 38th Annual Convention and Exhibition.

Barber, A.J., Tjokrosapoetro, S., Charlton, T.R., 1986. Mud volcanoes, shale diapirs, wrench faults and mélanges in accretionary complexes, Eastern Indonesia. AAPG Bulletin 70 1729-1741.

Berry, R.F., McDougall, I., 1986. Interpretation of Ar-40/Ar-39 and $\mathrm{K} / \mathrm{Ar}$ dating evidence from the Aileu Formation, East-Timor, Indonesia. Chemical Geology 59 (1), 43-58.

Bird, P.R., Cook, S.E., 1991. Permo-Triassic successions of the Kekneno area, West Timor: implications for paleogeography and basin evolution. Journal of Southeast Asian Earth Sciences 6, 359-371.

Boger, S.D., Spelbrink, L.G., Lee, R.I., Sandiford, M., Maas, R., Woodhead, J.D., 2016. Isotopic (U-Pb, Nd) and geochemical constraints on the origins of the Aileu and Gondwana sequences of Timor. Journal of Asian Earth Sciences 134, 330-351.

Brown, M., Earle, M.M., 1983. Cordierite-bearing schists and gneisses from Timor, eastern Indonesia: P-T implications of metamorphism and tectonic implications. Journal of Metamorphic Geology 1, 183-203.

Carter, D.J., Audley-Charles, M.G., Barber, A.J., 1976. Stratigraphical analysis of island arccontinental margin collision in eastern Indonesia. Journal of the Geological Society of London 132, 179-198.

Charlton, T.R., 1989. Stratigraphic correlation across an arc continent collision zone Timor and the Australian Northwest Shelf. Australian Journal of Earth Sciences 36 (2), 263-274

Charlton, T.R., 1991. Postcollision extension in arc-continent collision zones, eastern Indonesia. Geology 19 (1), 28-31.

Charlton, T.R., 2002a. The petroleum potential of West Timor. Proceedings, Indonesian Petroleum Association, 28th Annual Convention.

Charlton, T.R., 2002b. The structural setting and tectonic significance of the Lolotoi, Laclubar and Aileu metamorphic massifs, East Timor. Journal of Asian Earth Sciences 20, 851-865.

Charlton, T.R. et al., 2002. The Permian of Timor: stratigraphy, palaeontology and palaeogeography. Journal of Asian Earth Sciences 20 (6), 719-774.

Charlton, T.R., Barber, A.J., Barkham, S.T., 1991. The structural evolution of the Timor collision complex, eastern Indonesia. Journal of Structural Geology 13 (5), 489-500.
Charlton, T.R., Barber, A.J., McGowan, A.J., Nicoll, R.S., Roniewicz, E., Cook, S.E., Barkham, S.T., Bird, P.R., 2009. The Triassic of Timor: lithostratigraphy, chronostratigraphy and palaeogeography. Journal of Asian Earth Sciences 36 (4-5), 341-363.

Coughlin, T.J., O'Sullivan, P.B., Kohn, B.P., Holcombe, R.J., 1998. Apatite fission-track thermochronology of the Sierras Pampeanas, central western Argentina: implications for the mechanism of plateau uplift in the Andes. Geology 26 (11), 999-1002.

Cox, N.L., 2009. Variable Uplift From Quaternary Folding Along the Northern Coast of East Timor, Based on U-series Age Determinations of Coral Terraces. Brigham Young University (151 pp).

Davis, D., Suppe, J., Dahlen, F.A., 1983. Mechanics of fold-and-thrust belts and accretionary wedges. Journal of Geophysical Research 88 (Nb2), 1153-1172.

Davydov, V.I., Haig, D.W., McCartain, E., 2013. A latest Carboniferous warming spike recorded by a fusulinid-rich bioherm in Timor Leste: implications for East Gondwana deglaciation. Palaeogeography Palaeoclimatology Palaeoecology 376, 22-38.

Davydov, V.I., Haig, D.W., McCartain, E., 2014. Latest Carboniferous (Late Gzhelian) fusulinids from Timor Leste and their paleobiogeographic affinities. Journal of Paleontology 88 (3), 588-605.

De Smet, M.E.M., Fortuin, A.R., Troelstra, S.R., Vanmarle, L.J., Karmini, M., Tjokosaproetro, S., Hadiwasastra, S., 1990. Detection of collision-related vertical movements in the Outer Banda Arc (Timor, Indonesia), using micropaleontological data. Journal of Southeast Asian Earth Sciences 4 (4), 337-356.

Dewey, J.F., Bird, J.M., 1970. Mountain belts and new global tectonics. Journal of Geophysical Research 75 (14), 2625-2647.

Elburg, M.A., van Bergen, M.J., Foden, J.D., 2004. Subducted upper and lower continental crust contributes to magmatism in the collision sector of the Sunda-Banda Arc, Indonesia. Geology 32 (1), 41-44.

Ely, K.S., Sandiford, M., 2010. Seismic response to slab rupture and variation in lithospheric structure beneath the Savu Sea, Indonesia. Tectonophysics 483 (1-2), 112-124.

Ely, K.S., Sandiford, M., Hawke, M.L., Phillips, D., Quigley, M., dos Reis, J.E., 2011. Evolution of Atauro Island: temporal constraints on subduction processes beneath the Wetar zone, Banda Arc. Journal of Asian Earth Sciences 41 (6), 477-493.

Ely, K.S., Sandiford, M., Phillips, D., Boger, S.D., 2014. Detrital zircon U-Pb and 40Ar/39Ar hornblende ages from the Aileu Complex, Timor-Leste: provenance and metamorphic cooling history. Journal of the Geological Society of London 171 (2), 299-309.

Farley, K.A., 2002. (U-Th)/He dating: techniques, calibrations, and applications. Noble Gases in Geochemistry and Cosmochemistry 47, 819-844.

Fichtner, A., De Wit, M., van Bergen, M., 2010. Subduction of continental lithosphere in the Banda Sea region: combining evidence from full waveform tomography and isotope ratios. Earth and Planetary Science Letters 297 (3-4), 405-412.

Fillon, C., Huismans, R.S., van der Beek, P., 2013. Syntectonic sedimentation effects on the growth of fold-and-thrust belts. Geology 41 (1), 83-86.

Gaina, C., Torsvik, T.H., van Hinsbergen, D.J.J., Medvedev, S., Werner, S.C., Labails, C., 2013. The African Plate: a history of oceanic crust accretion and subduction since the Jurassic. Tectonophysics 604, 4-25.

Gradstein, F., Ogg, J., Schmitz, M., Ogg, G., 2012. The Geological Time Scale 2012. Elsevier. Haig, D.W., McCartain, E., 2007. Carbonate pelagites in the post-Gondwana succession (Cretaceous-Neogene) of East Timor. Australian Journal of Earth Sciences 54 (6), 875-897.

Haig, D.W McCartain, E 2010. Triassic organic-cemented siliceous agglutinated foraminifera from Timor Leste: conservative development in shallow-marine environments. Journal of Foraminiferal Research 40 (4), 366-392.

Hall, R., 2012. Late Jurassic-Cenozoic reconstructions of the Indonesian region and the Indian Ocean. Tectonophysics 570,1-41.

Harris, R., 1991. Temporal distribution of strain in the active Banda orogen: a reconciliation of rival hypotheses. Journal of Southeast Asian Earth Sciences 6, 373-386.

Harris, R., 2006. Rise and fall of the Eastern Great Indonesian arc recorded by the assembly, dispersion and accretion of the Banda Terrane, Timor. Gondwana Research 10 (3-4), 207-231.

Harris, R., 2011. The nature of the Banda Arc-continent collision in the Timor region. In: Ryan, D.B.a.P.D. (Ed.), Arc-Continent Collision. Springer, Heidelberg, Berlin, pp. 163-211.

Harris, R., Sawyer, R.K., Audley-Charles, M.G., 1998. Collisional melange development: geologic associations of active melange-forming processes with exhumed melange facies in the western Banda orogen, Indonesia. Tectonics 17 (3), 458-479.

Harris, R., Kaiser, J., Hurford, A., Carter, A., 2000. Thermal history of Australian passive margin cover sequences accreted to Timor during Late Neogene arc-continent collision, Indonesia. Journal of Asian Earth Sciences 18 (1), 47-69.

Harris, R., Vorkink, M.W., Prasetyadi, C., Zobell, E., Roosmawati, N., Apthorpe, M., 2009. Transition from subduction to arc-continent collision: geologic and neotectonic evolution of Savu Island, Indonesia. Geosphere 5 (3), 152-171.

Herrington, R.J., Scotney, P.M., Roberts, S., Boyce, A.J., Harrison, D., 2011. Temporal association of arc-continent collision, progressive magma contamination in arc volcanism and formation of gold-rich massive sulphide deposits on Wetar Island (Banda Arc). Gondwana Research 19 (3), 583-593.

Hildebrand, R.S., Bowring, S.A., 1999. Crustal recycling by slab failure. Geology 27 (1), 11-14.

van Hinsbergen, DJJ 2010. A key extensional metamorphic complex reviewed and restored: the Menderes Massif of western Turkey. Earth-Science Reviews 102, 60-76.

van Hinsbergen, D.J.J., Kouwenhoven, T.J., van der Zwaan, G.J., 2005. Paleobathymetry in the backstripping procedure: correction for oxygenation effects on depth estimates. Palaeogeography Palaeoclimatology Palaeoecology 221 (3-4), 245-265.

van Hinsbergen, D.J.J., Vissers, R.L.M., Spakman, W., 2014. Origin and consequences of western Mediterranean subduction, rollback, and slab segmentation. Tectonics 33 (4), 393-419.

Hurford, A.J., Green, P.F., 1983. The zeta-age calibration of fission-track dating. Isotope Geoscience 1 (4), 285-317. 
Karig, D.E., Barber, A.J., Charlton, T.R., Klemperer, S., Hussong, D.M., 1987. Nature and distribution of deformation across the Banda Arc-Australian collision zone at Timor. Geological Society of America Bulletin 98, 18-32.

Keep, M., Haig, D.W., 2010. Deformation and exhumation in Timor: distinct stages of a young orogeny. Tectonophysics 483 (1-2), 93-111.

Kenyon, C.S., Beddoes, L.R., 1977. Geothermal Gradient Map of Indonesia. 50 pp. Indonesian Petroleum Association, Southeast Asia Petroleum Exploration Society, Jakarta.

Ketcham, R.A., Donelick, R.A., Carlson, W.D., 1999. Variability of apatite fission-track annealing kinetics: III. Extrapolation to geological time scales. American Mineralogist 84 (9), 1235-1255.

Koulali, A., Susilo, S., McClusky, S., Meilano, I., Cummins, P., Tregoning, P., Lister, G., Efendi, J., Syafi'I, M.A., 2016. Crustal strain partitioning and the associated earthquake hazard in the eastern Sunda-Banda Arc. Geophysical Research Letters http://dx.doi.org/10. 1002/2016GL067941.

Lourens, L.J., Hilgen, F.J., Shackleton, N.J., Laskar, J., Wilson, D., 2004. The Neogene Period. In: Gradstein, F.M., Ogg, J.G., Smith, A.G. (Eds.), Geological Time Scale. Cambridge University Press, pp. 409-440.

Mccaffrey, R., Molnar, P., Roecker, S.W., Joyodiwiryo, Y.S., 1985. Microearthquake seismicity and fault plane solutions related to arc-continent collision in the eastern Sunda Arc, Indonesia. Journal of Geophysical Research 90 (Nb6), 4511-4528.

McKenzie, D.P., 1969. Speculations on the consequences and causes of plate motions. Geophysical Journal of the Royal Astronomical Society 18 (1), 1-32.

Merritts, D., Eby, R., Harris, R., Edwards, R.L., Cheng, H., 1998. Variable rates of Late Quaternary surface uplift along the Banda Arc-Australian Plate collision zone, Eastern Indonesia. In: Stewart, I.S., Vita-Finzi, C. (Eds.), Coastal Tectonics. Geological Society of London Special Publications 146, pp. 213-224.

van der Meulen, M.J., Buiter, S.J.H., Meulenkamp, J.E., Wortel, M.J.R., 2000. An early Pliocene uplift of the central Apenninic foredeep and its geodynamic significance. Tectonics 19 (2), 300-313.

Montgomery, D.R., Balco, G., Willett, S.D., 2001. Climate, tectonics, and the morphology of the Andes. Geology 29 (7), 579-582.

Nguyen, N., Duffy, B., Shulmeister, J., Quigley, M., 2013. Rapid Pliocene uplift of Timor. Geology 41, 179-182.

Nugroho, H., Harris, R., Lestariya, A.W., Maruf, B., 2009. Plate boundary reorganization in the active Banda Arc-continent collision: insights from new GPS measurements. Tectonophysics 479 (1-2), 52-65.

O'Brien, G.W., Lisk, M., Duddy, I., Eadington, P.J., Cadman, S., Fellows, M., 1996. Late Tertiary fluid migration in the Timor Sea: a key control on thermal and diagenetic histories? APPEA Journal 36, 399-427.

Perez, N.D., Horton, B.K., McQuarrie, N., Stübner, K., Ehlers, T.A., 2016. Andean shortening, inversion and exhumation associated with thin- and thick-skinned deformation in southern Peru. Geological Magazine 153 (5/6), 1013-1041.

Reed, T.A., de Smet, M.E.M., Harahap, B.H., Sjapawi, A., 1996. Structural and deformational history of East Timor. Proceedings, Indonesian Petroleum Association, 25th Annual Convention.

Reiners, P.W., Spell, T.L., Nicolescu, S., Zanetti, K.A., 2004. Zircon (U-Th)/He thermochronometry: He diffusion and comparisons with (40) $\mathrm{Ar} /(39) \mathrm{Ar}$ dating. Geochimica et Cosmochimica Acta 68 (8), 1857-1887.

Richardson, A.N., Blundell, D.J., 1996. Continental collision in the Banda Arc. Geological Society of London, Special Publication 106, 47-60.

Roosmawati, N., Harris, R., 2009. Surface uplift history of the incipient Banda arccontinent collision: geology and synorogenic foraminifera of Rote and Savu Islands, Indonesia. Tectonophysics 479 (1-2), 95-110.

Rosidi, H.M.D., Tjokrosapoetro, S., Gafoer, S., 1979. Geological Map of the Kupang-Atambua Quadrangles, Timor. Geological Research and Development Centre, Indonesia.

Sandiford, M., 2008. Seismic moment release during slab rupture beneath the Banda Sea. Geophysical Journal International 174 (2), 659-671.

Sani, K., Jacobson, M.L., Sigit, R., 1995. The thin-skinned thrust structures of Timor. Indonesian Petroleum Association 24th Annual Convention, Jakarta, pp. 277-293.

Saqab, M.M., Bourget, J., Trotter, J., Keep, M., 2017. New constrains on the timing of flexural deformation along the northern Australian margin: implications for arc-continent collision and the development of the Timor Trough. Tectonophysics 696-697, 14-36.

Sawyer, R.K., Sani, K., Brown, S., 1993. The stratigraphy and sedimentology of West Timor, Indonesia. Paper Presented at Proceedings Indonesian Petroleum Association.
Seton, M., et al., 2012. Global continental and ocean basin reconstructions since $200 \mathrm{Ma}$. Earth-Science Reviews 113 (3-4), 212-270.

Shulgin, A., Kopp, H., Mueller, C., Lueschen, E., Planert, L., Engels, M., Flueh, E.R. Krabbenhoeft, A., Djajadihardja, Y., 2009. Sunda-Banda arc transition: incipient continent-island arc collision (northwest Australia). Geophysical Research Letters 36.

Smith, W.H.F., Sandwell, D.T., 1997. Global sea floor topography from satellite altimetry and ship depth soundings. Science 277 (5334), 1956-1962.

Snyder, D.B., Prasetyo, H., Blundell, D.J., Pigram, C.J., Barber, A.J., Richardson, A., Tjokosaproetro, S., 1996. A dual doubly vergent orogen in the Banda Arc continent arc collision zone as observed on deep seismic reflection profiles. Tectonics 15 (1), 34-53.

Sobel, E.R., Oskin, M., Burbank, D., Mikolaichuk, A., 2006. Exhumation of basement-cored uplifts: example of the Kyrgyz Range quantified with apatite fission track thermochronology. Tectonics 25 (2), TC2008.

Spakman, W., Hall, R., 2010. Surface deformation and slab-mantle interaction during Banda arc subduction rollback. Nature Geoscience 3 (8), 562-566.

Spencer, C.J., Harris, R.A., Major, J.R., 2016. Provenance of Permian-Triassic Gondwana sequence units accreted to the Banda Arc in the Timor region: constraints from zircon $\mathrm{U}-\mathrm{Pb}$ and $\mathrm{Hf}$ isotopes. Gondwana Research 38, 28-39.

Stampfli, G.M., Hochard, C., 2009. Plate tectonics of the Alpine realm. Geological Society Special Publications 327, 89-111.

Standley, C.E., Harris, R., 2009. Tectonic evolution of forearc nappes of the active Banda arc-continent collision: origin, age, metamorphic history and structure of the Lolotoi Complex, East Timor. Tectonophysics 479 (1-2), 66-94.

Suppe, J., 1981. Mechanics of mountain building and metamorphism in Taiwan. Memoir of Geological Society of China 4, 67-89.

Suppe, J., 1983. Geometry and kinematics of fault-bend folding. American Journal of Science 283 (7), 684-721.

Suppe, J., 1984. Kinematics of arc-continent collision, flipping of subduction, and back-arc spreading near Taiwan. Memoir of Geological Society of China 6, 21-33.

Tate, G.W., McQuarrie, N., Van Hinsbergen, D.J.J., Bakker, R., Harris, R., Willett, S.D., Reiners, P.W., Fellin, M.G., Ganerod, M., Zachariasse, J., 2014. Resolving spatial heterogeneities in exhumation and surface uplift in Timor-Leste: constraints on deformation processes in young orogens. Tectonics 33 (6), 1089-1112.

Tate, G.W., McQuarrie, N., van Hinsbergen, D.J.J., Bakker, R.R., Harris, R., Jiang, H., 2015. Australia going down under: quantifying continental subduction during arccontinent accretion in Timor-Leste. Geosphere 11, 1860-1883.

Tripathi, A., Jones, W.B., Rajagopal, R., 2012. Insights into the petroleum potential of the Australian north west shelf and Arafura Sea reveled by regional 2D seismic data. International Petroleum Technology Conference, Bangkok, p. 15302.

Van Marle, L.J., 1988. Bathymetric distribution of benthic foraminifera on the AustralianIrian Jaya continental margin, eastern Indonesia. Marine Micropaleontology 13 97-152.

Van Marle, L.J., 1989. Recent and fossil benthic foraminifera and late Cenozoic paleobathymetry of Seram, eastern Indonesia. Netherlands Journal of Sea Research 24 (4), 445-457.

Van Marle, L.J., 1991. Eastern Indonesian, late Cenozoic smaller benthic foraminifera. Memoirs of the Royal Dutch Academy of Sciences, Physics Division 1 (34), 328.

Wade, B.S., Pearson, P.N., Berggren, W.A., Palike, H., 2011. Review and revision of Cenozoic tropical planktonic foraminiferal biostratigraphy and calibration to the geomagnetic polarity and astronomical time scale. Earth Science Reviews 104 (1-3), 111-142.

Willett, S.D., Brandon, M.T., 2013. Some analytical methods for converting thermochronometric age to erosion rate. Geochemistry, Geophysics, Geosystems 14 (1), 209-222.

Willett, S.D., Fisher, D., Fuller, C., En-Chao, Y., Lu, C.Y., 2003. Erosion rates and orogenicwedge kinematics in Taiwan inferred from fission-track thermochronometry. Geology 31 (11), 945-948.

Zimmermann, S., Hall, R., 2016. Provenance of Triassic and Jurassic sandstones in the Banda Arc: petrography, heavy minerals and zircon geochronology. Gondwana Research 37, 1-19.

Zobell, E.A., 2007. Origin and Tectonic Evolution of Gondwana Sequence Units Accreted to the Banda Arc: A Structural Transect Through Central East Timor. Brigham Young University (75 pp). 